\title{
Vehicle-Miles of Travel Statistics, Lifetime Vehicle-Miles of Travel, and Current State Methods of Estimating Vehicle-Miles of Travel
}

\author{
TERA, Inc. \\ David L. Greene \\ Andrew S. Loebl
}

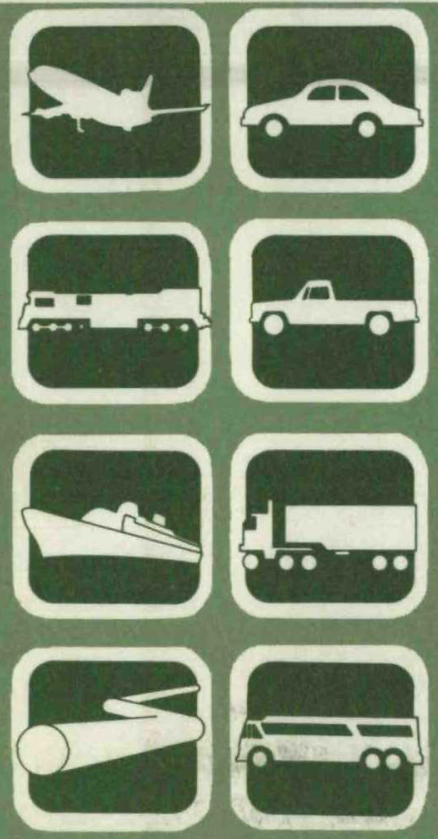

OAK RIDGE NATIONAL LABORATORY OPERATED BY UNION CARBIDE CORPORATION - FOR THE DEPARTMENT OF ENERGY 
Printed in the United States of America. Available from National Technical Information Service

U.S. Department of Commerce 5285 Port Royal Road, Springfield, Virginia 22161

Price: Printed Copy $\$ 6.00$; Microfiche $\$ 3.00$

This report was prepared as an account of work sponsored by an agency of the United States Government. Neither the United States Government nor any agency thereof, nor any of their employees, contractors, subcontractors, or their employees, makes any warranty, express or implied, nor assumes any legal liability or responsibility for any third party's use or the results of such use of any information, apparatus, product or process disclosed in this report, nor represents that its use by such third party would not infringe privately owned rights. 


\section{DISCLAIMER}

This report was prepared as an account of work sponsored by an agency of the United States Government. Neither the United States Government nor any agency Thereof, nor any of their employees, makes any warranty, express or implied, or assumes any legal liability or responsibility for the accuracy, completeness, or usefulness of any information, apparatus, product, or process disclosed, or represents that its use would not infringe privately owned rights. Reference herein to any specific commercial product, process, or service by trade name, trademark, manufacturer, or otherwise does not necessarily constitute or imply its endorsement, recommendation, or favoring by the United States Government or any agency thereof. The views and opinions of authors expressed herein do not necessarily state or reflect those of the United States Government or any agency thereof. 


\section{DISCLAIMER}

Portions of this document may be illegible in electronic image products. Images are produced from the best available original document. 
Contract No. W-7405-eng-26

\author{
VEHICLE-MILES OF TRAVEL STATISTICS, LIFETIME VEHICLE-MILES \\ OF TRAVEL, AND CURRENT STATE METHODS OF \\ ESTIMATING VEHICLE-MILES OF TRAVEI
}

TERA, Inc.

ORNL P.0. No. 11X-13507V*

*Parts of this report are from two studies by TERA, Inc.

\author{
David L. Greene \\ Andrew S. Loeb1 \\ Regional and Urban Studies Section \\ Energy Division
}

\begin{abstract}
Prepared for
Data Analysis Branch

Nonhighway Transport Systems and Special Projects

Transportation Energy Conservation Division Office of Conservation and Solar Applications

Department of Energy
\end{abstract}

Date Published: February 1979

OAK RIDGE NATIONAL LABORATORY

Oak Ridge, Tennessee 37830

operated by

UNION CARBIDE CORPORTAION

for the

DEPARTMENT OF ENERGY 
-

○ 
LIST OF FIGURES . . . . . . . . . . . . . . . . . . . . v v

LIST OF TABLES . . . . . . . . . . . . . . . . . . . . . . vii

FOREWORD . . . . . . . . . . . . . . . . . . . . . ix

EXECUTIVE SUMMARY . . . . . . . . . . . . . . . . . . . . . xi

ABSTRACT . . . . . . . . . . . . . . . . . . . . . xiii

1. INTRODUCTION . . . . . . . . . . . . . . . . . . . . . . . . . 1

2. VMT DATA SOURCES .. . . . . . . . . . . . . . . . 3

2.1 Highway VMT Data . . . . . . . . . . . . . . . . 5

2.2 Rail VMT Data . . . . . . . . . . . . . . 12

2.3 Air VMT Data . . . . . . . . . . . . . . . . . 13

2.4 Findings and Recommendations . . . . . . . . . . . . 13

2.5 Lifetime VMT . . . . . . . . . . . . . . . . . . . 14

2.6 LVMT for Trucks . . . . . . . . . . . . . . . . . 15

2.7 LVMT for Passenger Cars . . . . . . . . . . . . . 18

3. CURRENT STATE PRACTICES TO ESTIMATE VMT . . . . . . . . . . . 21

3.1 Introduction . . . . . . . . . . . . . . . . . 21

3.2 Traffic Count Method . . . . . . . . . . . . . . 25

3.3 Fuel Consumption Method . . . . . . . . . . . . . 26

3.4 Individual State Practices to Estimate VMT . . . . . . . 26

4. STATISTICAL ANALYSIS OF STATE VMT ESTIMATES . . . . . . . . . 53

4.1 Descriptive Statistics . . . . . . . . . . . . . . . 55

4.2 Analysis of Covariance . . . . . . . . . . . . . . . 55

4.3 Variability of VMT Estimates . . . . . . . . . . . 63

4.4 Conclusions . . . . . . . . . . . . . . . . . . . 65

APPENDIX - STATE OF OFFICIALS CONTACTED CONCERNING TERA VMT

DATA . . . . . . . . . . . . . . . . . . . 69 
-

○ 
LIST OF FIGURES

Figure

Page

1. Total vehicle-miles traveled by mode, 1975 ....... . 4

2. Schematic representation of the FHWA approach by use of 1975 data. . . . . . . . . . . . . 8

3. Method of estimating LVMT for trucks . . . . . . . . 16

4. Dependence of rate of increase of VMT (Model 1) on the value of $b . . . . . . . . . . . . .557$

V 
•

• 


\section{LIST OF TABLES}

Table

$\underline{\text { Page }}$

1. Estimated motor-vehicle travel in the United States and related data (1975 and revised 1974) . . . . . . 6

2. Vehicle-miles by state and highway system - 1975 . . . . . 7

3. Average annual-miles traveled per car - results of nine surveys . . . . . . . . . . . . . . . . 10

4. Lifetime data for passenger cars . . . . . . . . . 15

5. 1971-75 average miles per gallon and percent change by state . . . . . . . . . . . . . . . . . . . . 22

6. 1971-75 average annual-miles per vehicle and percent change by state. . . . . . . . . . . . . . . . 23

7. 1971-75 annual vehicle-miles per household and percent change by state.................. . 24

8. Comparative summary of state practices to estimate VMT ................... 27

9. States by method of estimating vehicle-miles of trave1.................... . 54

10. Analysis of covariance sums of squares and test statistics for model 1 . . . . . . . . . . . . . 59

11. Analysis of covariance sums of squares and test statistics for model 2 . . . . . . . . . . . . . 60

12. Analysis of covariance sums of squares and test statistics for mode1 3 . . . . . . . . . . . . 61

13. Tests for equality of variance of error in models 1-3 . . . . . . . . . . . . . . . . . 64 
-

0 
FOREWORD

This report on vehicle-miles traveled (VMT) statistics for air, highway, and rail transportation of passengers and freight is a guide to those who use VMT data and need further information on the background of published VMT statistics. The TERA (Transportation and Economic

Research Associates) studies * reviewed published sources to trace VMT data to their origins. These TERA studies include the scope, definition, and methods of collection of VMT statistics.

The TERA reports were edited and condensed for this publication by Judith Arehart of ORNL. Final editing was by Dr. George Griffith.

Dr. David L. Greene of ORNL authored the statistical analysis of VMT estimates. Jennifer Leack of the University of Tennessee provided the research assistance in the statistical analysis.

This report is one of a series of subcontract reports. Each report represents a specific topic directed at research related to a basic concept in transportation energy use. The work was done in support of the Oak Ridge National Laboratory's transportation energy program, which is an area of study for the Data Management and Analysis Group of the Energy Division and is under the direction of Dr. Andrew S. Loebl.

"Existing Data on Vehicle-Miles Traveled in the United States, July 1977 and Lifetime VMT and Current State Practices to Estimate VMT, October 1977, ORNL P.O. Contract No. 11X-13507V. 
○

○ 


\title{
EXECUTIVE SUMMARY
}

Two studies of annual vehicle-miles of travel (VMT) in the United States based on VMT data and the cumulative lifetime VMT of automobiles and trucks respectively were recently completed by TERA Associates under subcontract to ORNL. A third study, completed by ORNL, was a statistical analysis of state VMT estimates. This latter investigation used information included in the TERA reports on state methods of estimating VMT.

In the TERA study of VMT data sources, investigators found that only one primary source of VMT data could be relied upon for each category in annually reported VMT statistics:

\author{
Rail - Intercity: Interstate Commerce Commission \\ Intracity: American Public Transit Association \\ Freight: Association of American Railroads \\ Air - Certificated Carriers: Civil Aeronautics Board \\ General Aviation: Federal Aviation Administration \\ Highway - Total: Federal Highway Administration (FHWA) \\ Federal Fleet: General Services Administration \\ Taxis: International Taxicab Association \\ Bus - Intercity: National Association of Motor Bus \\ Operators (Now American Bus Association) \\ Intracity: American Public Transit Association \\ Total highway VMT statistics are compiled by FHWA from state estimates. \\ States estimate VMT on three different bases: Traffic count (used by \\ 23 states and the District of Columbia), fuel use, (11 states), or a com- \\ bination of the two (16 states). \\ TERA's study of automobile and truck lifetime VMT concluded that: \\ - Average annual-miles for trucks is considerably higher than for \\ passenger cars. \\ - Between 1967 and 1976 the average age of retirement for trucks was \\ 11.07-12.43 y. Over the same period, the average age of retirement \\ for cars was 9.29-10.76 y.
}


- Simple time trends in lifetime VMT were not perceptible for either trucks or cars between 1967-76.

- Average retirement age is a more important determinant of lifetime VMT than is average annual VMT. That is, during 1967-76 the length of service of vehicles had a greater influence on lifetime VMT than did the intensity of use. This relationship was more pronounced for cars than for trucks.

ORNL's statistical analysis of state VMT estimates sought systematic differences among the estimates produced by the three different methods used by states. This investigation used 1966-75 data and found that:

- Estimates by traffic count showed greater variability than estimates by the other methods.

- Despite differences in the variability of estimates derived from the three methods, no significant systematic differences appeared in the way state VMT estimates changed in response to changes in state incomes and fuel prices. 


\section{ABSTRACT}

This comprehensive review of current statistics on vehicle-miles of travel (VMT) in the United States identifies and evaluates sources of national VMT data for highway, rail, and air travel. From available information, VMT statistics by form of travel have been compiled for 1975. Vehicle 1ifetime VMT is estimated separately for passenger cars and trucks.

A survey of state practices in estimating VMT shows that states use one of three methods: (1) the fuel consumption method, (2) the traffic count method, or (3) a combination of the two. An analysis of state VMT statistics indicates a surprising degree of consistency among the three methods despite significant differences in the variability of estimates produced by the three methods. 


\section{INTRODUCTION}

Transportation is a significant user of scarce energy resources. In 1975, it has produced in excess of 2 trillion ton-miles and 2.5 trillion passenger-miles and used about $55 \%$ of the nation's petroleum products (26\% of its energy). The ability to meet future energy challenges depends largely upon the development and use of more energy-efficient technologies and operations. Evaluation of alternatives in transportation requires accurate and comprehensive data on the nature and extent of energy use. Such an evaluation also requires continuous compilation of data on VMT because VMT links energy inputs into transportation with the ton-mile and passenger-mile outputs.

Various sources compile and publish VMT statistics. Depending upon the available means, the scope of coverage of data, the population surveyed, and the uses for the data, the published figures for VMT differ, even within categories. There are additional problems in the labeling or description of published data. 
$$
\text { . }
$$ 


\section{VMT DATA SOURCES}

VMT statistics are available periodically for only highway, rail, and air transportation (Fig. 1). No source regularly compiles and reports VMT data for pipeline and water transport. Total VMT for road, rail, and air transport is nearly 1.4 trillion for 1975, the most recent year for which data are available. A distinction is made between passenger and freight use for highway and rail transport, although some small trucks provide passenger transportation (Fig. 1).

An unqualified distinction between passenger and freight transportation by air is not possible because most flights include both passenger and cargo. Instead, VMT by freight-only flights has been reported under air cargo. All of the VMT of predominantly passenger flights which also carry freight has been reported as passenger VMT.

Ownership patterns of vehicles may be useful because future federal policy towards energy conservation in transportation may have different degrees of compliance from government fleets than from nongovernment fleets. Compliance may be required by law, or through voluntary measures. The probable results will depend upon the method of introducing change, so a distinction in ownership categories seems justified. This is not the case for rail transport because federal ownership of railroads is limited to Alaska. (AMTRAK and CONRAIL are federally funded but not federally owned.) For air transport, no distinction is possible because data on military aircraft-miles traveled are not publicly available. Data may be further divided into categories by vehicle and service types (Fig. 1) .

VMT data have been compiled from the following eight primary sources:

- U.S. Department of Transportation, Federal Highway Administration (FHWA),

- Interstate Commerce Commission (ICC),

- General Services Administration (GSA),

- International Taxicab Association (ITA),

- National Association of Motor Bus Owners (NAMBO), 


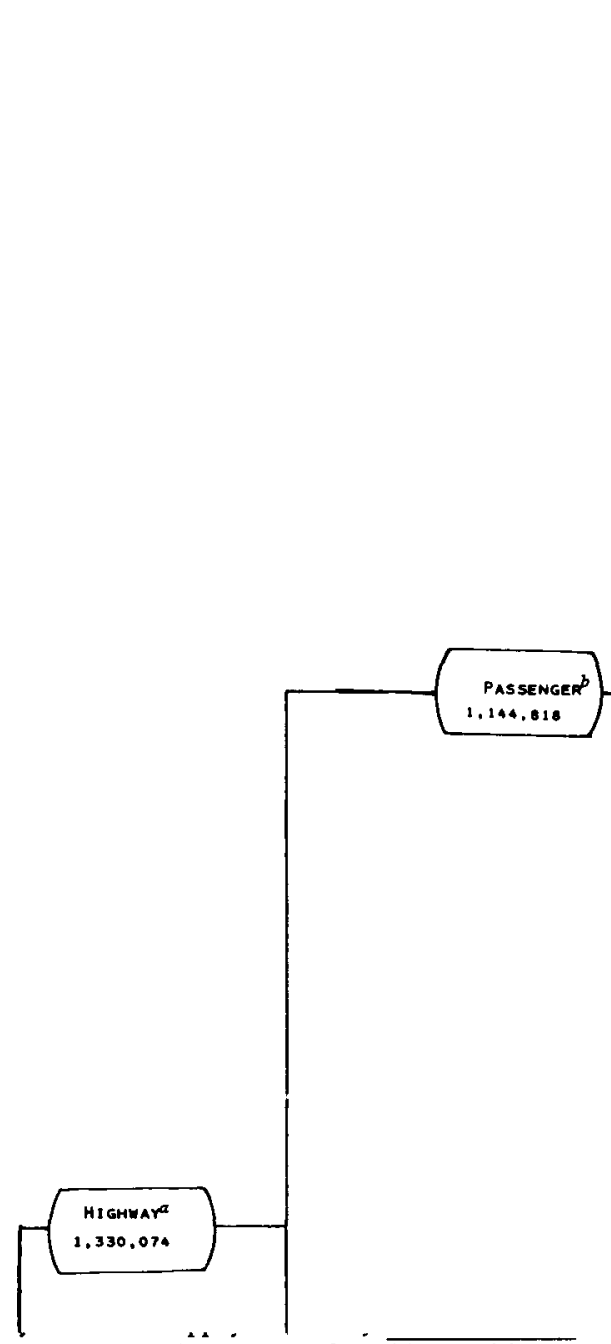

vehicle Fleet Report, Washington, D.C., July 1976 , Table $\overline{10, \text { p. } 16 .}$

$k_{\text {Same as }} j$ above with total bus information controlled to those published in note $a$ above.

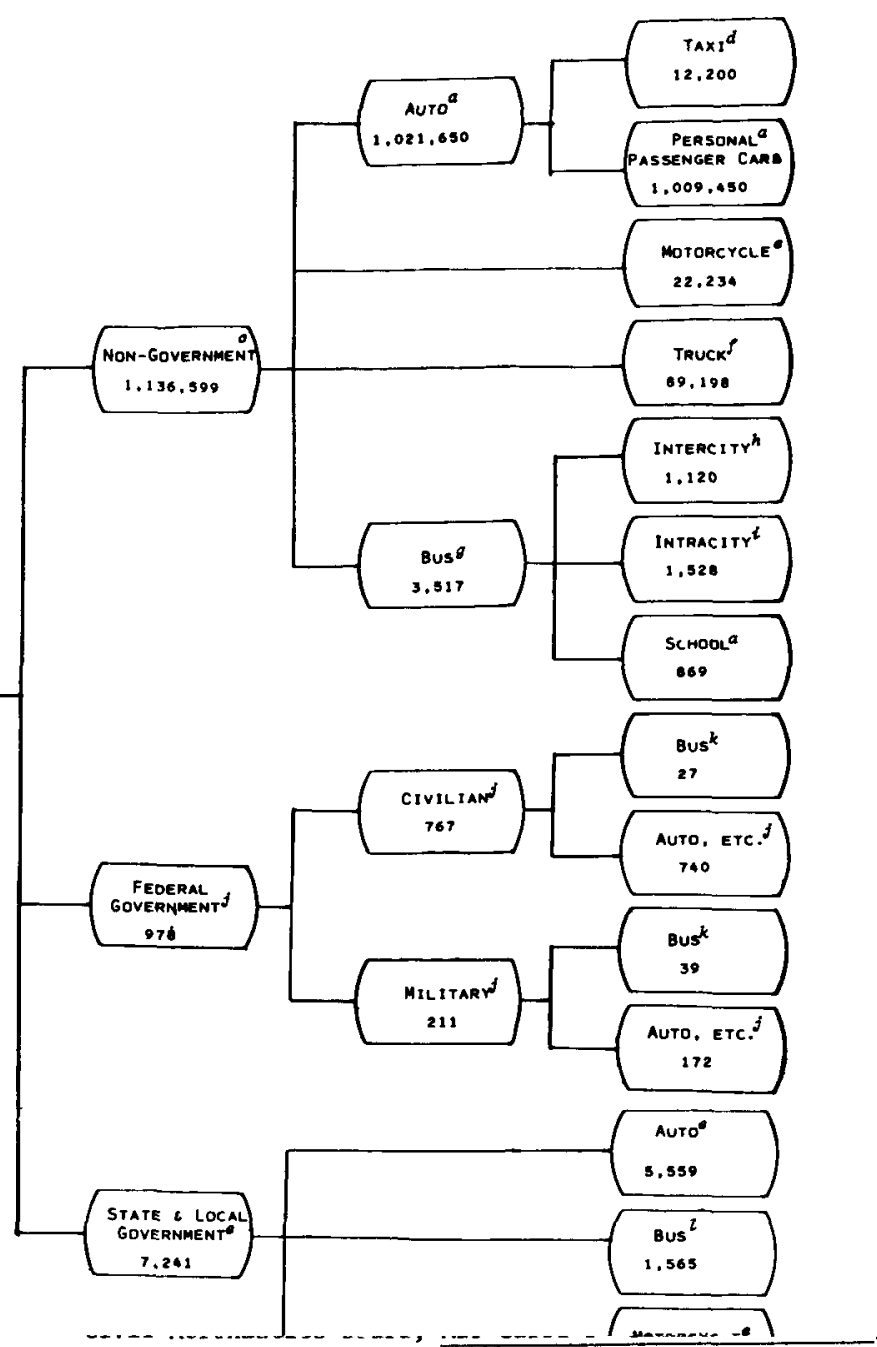

Sept. 1976, vol. xx11-9,

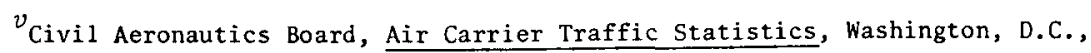
Sept. 1976, vo1. XX11-9, p. 9.

Fig. 1. Total vehicle-miles traveled by mode, 1975 (in millions of miles). 
- American Public Transit Association (APTA),

- Civil Aeronautics Board (CAB),

- U.S. Department of Transportation, Federal Aviation Administration (FAA).

2.1 Highway VMT data

Passenger and freight transportation data are divided into categories according to institutional ownership, vehicle type, and urban or rural location (Fig. 1). The controlling figure is the total VMT on highways published by the FHWA (Table 1).* Significant differences appear between the TERA data (Fig. 1) and the FHWA data (Table 1); the foremost difference is that FHWA distinguishes between passenger and cargo vehicles; TERA distinguishes between passenger and freight transportation. As much as $32.5 \%$ of the total truck VMT in 1972 was for personal transportation. ${ }^{1}$ This is significant, for TERA's report puts personal transportation by trucks in the passenger transportation category. This is appropriate for trucks "used in place of an automobile to go from home to work; for outdoor recreation; camping; fishing, etc."2

\subsubsection{FHWA approach}

The Federal Highway Administration (FHWA) compiles and publishes annually data submitted by state highway and transportation departments (Table 1). State Departments of Transportation submit the state total VMT for all vehicles and the number of registered vehicles by vehicle category. These state VMT data are published by highway system by FHWA as an aggregate figure for all vehicles used in highway transportation (Table 2). The FHWA approach (Fig. 2) to preparing VMT data (Table 1) differs each year, depending upon the data available and the analyst.

Subsequent to the writing of TERA's report, FHWA produced an expansion and clarification of the procedures used to construct Table VM-1. That report, which in part is based on TERA's earlier report, was available in draft at the time of publication: U.S. Department of Transportation, Highway Statistics Division, "Annual Estimates of Vehicle-Miles of Travel and Related Data by Vehicle Type for FHWA Table VM-1," Draft January 1978. 
Table 1. Estimated Motor-Vehıcle Travel in the United States and Related Data ${ }^{a}$ (1975 and Rev1sed 1974)

\begin{tabular}{|c|c|c|c|c|c|c|c|c|c|c|c|c|}
\hline \multirow[b]{3}{*}{ Year } & \multirow[b]{3}{*}{ I tem } & \multicolumn{6}{|c|}{ Passenger vehicles } & \multicolumn{4}{|c|}{ Cargo vehicles } & \multirow{3}{*}{$\begin{array}{l}\text { All } \\
\text { motor } \\
\text { vehicles }\end{array}$} \\
\hline & & \multicolumn{3}{|c|}{ Personal passenger vehicles } & \multicolumn{3}{|c|}{ Buses } & \multirow{2}{*}{$\begin{array}{l}\text { A11 } \\
\text { passenger } \\
\text { vehicles }\end{array}$} & \multirow{2}{*}{$\begin{array}{l}\text { Single- } \\
\text { unit } \\
\text { trucks }\end{array}$} & \multirow[b]{2}{*}{$\begin{array}{l}\text { Combi- } \\
\text { nations }\end{array}$} & \multirow[b]{2}{*}{$\begin{array}{l}\text { A11 } \\
\text { trucks }\end{array}$} & \\
\hline & & $\begin{array}{l}\text { Passenger } \\
\text { cars }\end{array}$ & $\begin{array}{l}\text { Motor- }-b \\
\text { cycles }\end{array}$ & \begin{tabular}{l}
\multicolumn{1}{c}{ All } \\
personal \\
passenger \\
vehicles
\end{tabular} & Commercial & $\begin{array}{l}\text { School } \\
\text { and other } \\
\text { nonrevenue }\end{array}$ & $\begin{array}{c}\text { A11 } \\
\text { buses }\end{array}$ & & & & & \\
\hline & $\begin{array}{l}\text { Motor-vehicle travel. } \\
\quad(\text { m1llion vehicle-miles) }\end{array}$ & & & & & & & & & & & \\
\hline $\begin{array}{l}1975 \\
1974\end{array}$ & Main rural roads & & & $\begin{array}{l}329,050 \\
313,703\end{array}$ & $\begin{array}{l}928 \\
965\end{array}$ & $\begin{array}{l}930 \\
920\end{array}$ & $\begin{array}{l}1,858 \\
1,885\end{array}$ & $\begin{array}{l}330,908 \\
315,588\end{array}$ & $\begin{array}{l}90,410 \\
86,062\end{array}$ & $\begin{array}{l}44,317 \\
44,562\end{array}$ & $\begin{array}{l}134,727 \\
130,624\end{array}$ & $\begin{array}{l}465,635 \\
446,212\end{array}$ \\
\hline $\begin{array}{l}1975 \\
1974\end{array}$ & Local rural roads & & & $\begin{array}{l}111,848 \\
113,606\end{array}$ & $\begin{array}{l}80 \\
90\end{array}$ & $\begin{array}{l}1,020 \\
1,010\end{array}$ & $\begin{array}{l}1,100 \\
1,100\end{array}$ & $\begin{array}{l}112,948 \\
114,706\end{array}$ & $\begin{array}{l}20,712 \\
21,169\end{array}$ & $\begin{array}{l}1,336 \\
1,387\end{array}$ & $\begin{array}{l}22,048 \\
22,556\end{array}$ & $\begin{array}{l}134,996 \\
137,262\end{array}$ \\
\hline $\begin{array}{l}1975 \\
1974\end{array}$ & A11 rural roads & & & $\begin{array}{l}440,898 \\
427,309\end{array}$ & $\begin{array}{l}1,008 \\
1,055\end{array}$ & $\begin{array}{l}1,950 \\
1,930\end{array}$ & $\begin{array}{l}2,958 \\
2,985\end{array}$ & $\begin{array}{l}443,856 \\
430,294\end{array}$ & $\begin{array}{l}111,122 \\
107,231\end{array}$ & $\begin{array}{l}45,653 \\
45,949\end{array}$ & $\begin{array}{l}156,775 \\
153,180\end{array}$ & $\begin{array}{l}600,631 \\
583,474\end{array}$ \\
\hline $\begin{array}{l}1975 \\
1974\end{array}$ & Urban streets & & & $\begin{array}{l}609,574 \\
585,759\end{array}$ & $\begin{array}{l}1,640 \\
1,555\end{array}$ & $\begin{array}{l}550 \\
520\end{array}$ & $\begin{array}{l}2,190 \\
2,075\end{array}$ & $\begin{array}{l}611,764 \\
587,834\end{array}$ & $\begin{array}{l}107,772 \\
104,229\end{array}$ & $\begin{array}{r}9,907 \\
10,110\end{array}$ & $\begin{array}{l}117,679 \\
114,339\end{array}$ & $\begin{array}{l}729,443 \\
702,173\end{array}$ \\
\hline $\begin{array}{l}1975 \\
1974\end{array}$ & Total travel & $\begin{array}{r}1,028,121 \\
990,721\end{array}$ & $\begin{array}{l}22,351 \\
22,347\end{array}$ & $\begin{array}{l}1,050,472 \\
1,013,068\end{array}$ & $\begin{array}{l}2,648 \\
2,610\end{array}$ & $\begin{array}{l}2,500 \\
2,450\end{array}$ & $\begin{array}{l}5,148 \\
5,060\end{array}$ & $\begin{array}{l}1,055,620 \\
1,018,128\end{array}$ & $\begin{array}{l}218,894 \\
211,460\end{array}$ & $\begin{array}{l}55,560 \\
56,059\end{array}$ & $\begin{array}{l}274,454 \\
267,519\end{array}$ & $\begin{array}{l}1,330,074 \\
1,285,647\end{array}$ \\
\hline $\begin{array}{l}1975 \\
1974\end{array}$ & $\begin{array}{l}\text { Number of vehicles registered } \\
\text { (thousands) }\end{array}$ & $\begin{array}{l}106,712.6 \\
104,856.3\end{array}$ & $\begin{array}{l}4,966.8 \\
4,966.4\end{array}$ & $\begin{array}{l}111,679.4 \\
109,822.7\end{array}$ & $\begin{array}{l}93.8 \\
901\end{array}$ & $\begin{array}{l}368.3 \\
356.9\end{array}$ & $\begin{array}{l}462.1 \\
447.0\end{array}$ & $\begin{array}{l}112,141.5 \\
110,269.7\end{array}$ & $\begin{array}{l}24,644.7 \\
23,545.2\end{array}$ & $\begin{array}{l}1,131.0 \\
1,085.0\end{array}$ & $\begin{array}{l}25,775.7 \\
24,630.2\end{array}$ & $\begin{array}{l}137,917.2 \\
134,8999\end{array}$ \\
\hline $\begin{array}{l}1975 \\
1974\end{array}$ & $\begin{array}{l}\text { Average miles traveled } \\
\text { per vehicle }\end{array}$ & $\begin{array}{l}9,634 \\
9,448\end{array}$ & $\begin{array}{l}4,500 \\
4,500\end{array}$ & $\begin{array}{l}9,406 \\
9,225\end{array}$ & $\begin{array}{l}28,230 \\
28,968\end{array}$ & $\begin{array}{l}6,788 \\
6,865\end{array}$ & $\begin{array}{l}11,140 \\
11,320\end{array}$ & $\begin{array}{l}9,413 \\
9,233\end{array}$ & $\begin{array}{l}8,882 \\
8,981\end{array}$ & $\begin{array}{l}49,125 \\
51,667\end{array}$ & $\begin{array}{l}10,648 \\
10,861\end{array}$ & $\begin{array}{l}9,644 \\
9,530\end{array}$ \\
\hline $\begin{array}{l}1975 \\
1974\end{array}$ & $\begin{array}{l}\text { Fuel consumed } \\
\text { (million gallons) }\end{array}$ & $\begin{array}{l}76,010 \\
73,770\end{array}$ & $\begin{array}{l}447 \\
447\end{array}$ & $\begin{array}{l}76,457 \\
74,217\end{array}$ & $\begin{array}{l}553 \\
525\end{array}$ & $\begin{array}{l}342 \\
333\end{array}$ & $\begin{array}{l}895 \\
858\end{array}$ & $\begin{array}{l}77,352 \\
75,075\end{array}$ & $\begin{array}{l}21,868 \\
21,125\end{array}$ & $\begin{array}{r}9,764 \\
10,101\end{array}$ & $\begin{array}{l}31,632 \\
31,226\end{array}$ & $\begin{array}{l}108,984 \\
106,301\end{array}$ \\
\hline $\begin{array}{l}1975 \\
1974\end{array}$ & $\begin{array}{l}\text { Average fuel consumption per } \\
\text { vehicle (gallons) }\end{array}$ & $\begin{array}{l}712 \\
704\end{array}$ & $\begin{array}{l}90 \\
90\end{array}$ & $\begin{array}{l}685 \\
676\end{array}$ & $\begin{array}{l}5,896 \\
5,827\end{array}$ & $\begin{array}{l}929 \\
933\end{array}$ & $\begin{array}{l}1,937 \\
1,919\end{array}$ & $\begin{array}{l}690 \\
681\end{array}$ & $\begin{array}{l}887 \\
897\end{array}$ & $\begin{array}{l}8,633 \\
9,310\end{array}$ & $\begin{array}{l}1,227 \\
1,268\end{array}$ & $\begin{array}{l}790 \\
788\end{array}$ \\
\hline $\begin{array}{l}1975 \\
1974\end{array}$ & $\begin{array}{l}\text { Average miles traveled per } \\
\text { gallon of fuel consumed }\end{array}$ & $\begin{array}{l}13.53 \\
13.43\end{array}$ & $\begin{array}{l}50.00 \\
50.00\end{array}$ & $\begin{array}{l}13.74 \\
13.65\end{array}$ & $\begin{array}{l}4.79 \\
4.97\end{array}$ & $\begin{array}{l}7.31 \\
7.36\end{array}$ & $\begin{array}{l}5.75 \\
5.90\end{array}$ & $\begin{array}{l}13.65 \\
13.56\end{array}$ & $\begin{array}{l}10.01 \\
10.01\end{array}$ & $\begin{array}{l}5.69 \\
5.55\end{array}$ & $\begin{array}{l}8.68 \\
8.57\end{array}$ & $\begin{array}{l}1220 \\
12.09\end{array}$ \\
\hline
\end{tabular}

$a_{\text {For the }} 50$ states and District of Columbia.

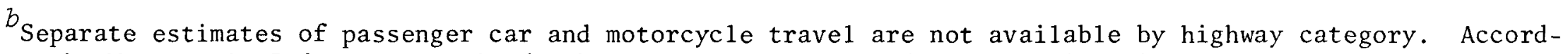
ing to the Motorcycle Industry Council (MIC), motorcycles traveled 12.6 billion miles in 1976, and there were 8.3 million motorcycles in use. See MIC's 1977 Motoreycle Statistical Annual, Newport Beach, Calif., p. 32.

Source: Highway Statistics Division, Office of Highway Planning, FHWA, Table VM-1, January 1977. 


\begin{tabular}{|c|c|c|c|c|c|c|c|c|c|c|c|c|c|c|c|c|c|c|c|c|c|c|c|c|c|c|c|}
\hline \multirow{4}{*}{$\begin{array}{l}\text { Federal } \\
\text { Fighway } \\
\text { adminis- } \\
\text { tration } \\
\text { region }\end{array}$} & \multirow[b]{4}{*}{ State } & \multirow{2}{*}{\multicolumn{19}{|c|}{ Federa1-aid highway systems }} & \multicolumn{4}{|c|}{ Not on federal-aid systems } & \multirow{4}{*}{\multicolumn{2}{|c|}{$\begin{array}{l}\text { Tota1 } \\
\text { urban } \\
\text { and } \\
\text { munici- } \\
\text { pa1 }\end{array}$}} & \multirow[b]{4}{*}{ Tota1 } \\
\hline & & & & & & & & & & & & & & & & & & & & & \multirow{3}{*}{$\begin{array}{l} \\
\text { Other } \\
\text { state } \\
\text { rura1 }\end{array}$} & \multirow{3}{*}{$\begin{array}{l}\text { Other } \\
\text { state } \\
\text { urban } \\
\text { and } \\
\text { munici- } \\
\text { pa1 }\end{array}$} & \multirow[b]{3}{*}{$\begin{array}{l}\text { Local } \\
\text { rural }\end{array}$} & \multirow{3}{*}{$\begin{array}{l}\text { Local } \\
\text { urban } \\
\text { and } \\
\text { munici- } \\
\text { pal }\end{array}$} & & & \\
\hline & & \multicolumn{3}{|c|}{ Interstate rural } & \multicolumn{3}{|c|}{ Interstate urban } & \multirow{2}{*}{$\begin{array}{l}\text { Total } \\
\text { inter- } \\
\text { state }\end{array}$} & \multicolumn{3}{|c|}{ other primary } & \multicolumn{5}{|c|}{ Secondary } & \multirow{2}{*}{$\begin{array}{c}\text { Federal- } \\
\text { aid } \\
\text { urban }\end{array}$} & \multicolumn{3}{|c|}{ Total federal-aid } & & & & & & & \\
\hline & & Final & $\begin{array}{l}\text { Trave1 ed- } \\
\text { way }\end{array}$ & $\begin{array}{l}\text { Tota1 } \\
\text { rura1 }\end{array}$ & Final & $\begin{array}{l}\text { Traveled- } \\
\text { way }\end{array}$ & $\begin{array}{l}\text { Tota1 } \\
\text { urban }\end{array}$ & & Rura1 & Urban & Tota1 & $\begin{array}{l}\text { State } \\
\text { rura1 }\end{array}$ & $\begin{array}{l}\text { State } \\
\text { urban }\end{array}$ & $\begin{array}{c}\text { Local } \\
\text { ruraal }\end{array}$ & $\begin{array}{c}\text { Local } \\
\text { urban }\end{array}$ & Total & & $\overline{\text { Rura1 }}$ & Urban & Total & & & & & & & \\
\hline Region 1 & $\begin{array}{l}\text { Connecticut } \\
\text { Maine } \\
\text { Massachusetts } \\
\text { New Hampshire } \\
\text { New Jersey } \\
\text { New York } \\
\text { Rhode Island } \\
\text { Vermont } \\
\text { Total }\end{array}$ & $\begin{array}{r}507 \\
609 \\
1,553 \\
629 \\
1,066 \\
3,663 \\
118 \\
610 \\
8,845\end{array}$ & $\begin{array}{r}296 \\
162 \\
34 \\
26 \\
117 \\
319 \\
22 \\
44\end{array}$ & $\begin{array}{r}803 \\
801 \\
1,587 \\
655 \\
1,183 \\
4,012 \\
170 \\
654 \\
9,865\end{array}$ & $\begin{array}{r}3,410 \\
121 \\
4,935 \\
214 \\
3,945 \\
6,864 \\
902 \\
46 \\
20,437\end{array}$ & $\begin{array}{r}504 \\
16 \\
98 \\
62 \\
704 \\
436 \\
87 \\
9\end{array}$ & $\begin{array}{r}3,914 \\
137 \\
5,033 \\
276 \\
4,649 \\
7,300 \\
989 \\
55 \\
52,353\end{array}$ & $\begin{array}{r}4,717 \\
{ }_{938} \\
6,620 \\
931 \\
5,832 \\
5,832 \\
11,312 \\
1,159 \\
709\end{array}$ & $\begin{array}{r}1,089 \\
1,579 \\
2,200 \\
1,488 \\
3,093 \\
9,293 \\
398 \\
976\end{array}$ & $\begin{array}{r}2,350 \\
522 \\
8,810 \\
358 \\
6,611 \\
11,592 \\
1,461 \\
264 \\
31,968\end{array}$ & $\begin{array}{r}3,439 \\
2,101 \\
11,010 \\
1,846 \\
9,704 \\
20,885 \\
1,859 \\
1,240 \\
52,084\end{array}$ & $\begin{array}{r}975 \\
1,045 \\
490 \\
851 \\
67 \\
2,657 \\
253 \\
510 \\
6,848\end{array}$ & $\begin{array}{r}- \\
220 \\
1,170 \\
77 \\
-7 \\
1,270 \\
496 \\
16 \\
3,249\end{array}$ & $\begin{array}{r}15 \\
850 \\
4 \\
4 \\
1,649 \\
1,921 \\
19 \\
190 \\
4,648\end{array}$ & $\begin{array}{r}- \\
- \\
2,500 \\
3 \\
- \\
1,009 \\
209 \\
13 \\
3,734\end{array}$ & $\begin{array}{r}990 \\
1,265 \\
5,010 \\
935 \\
1,716 \\
6,857 \\
977 \\
729 \\
18,479\end{array}$ & $\begin{array}{r}5,749 \\
122 \\
2,900 \\
611 \\
12,034 \\
5,542 \\
671 \\
28 \\
27,657\end{array}$ & $\begin{array}{r}2,882 \\
3,425 \\
5,127 \\
2,998 \\
5,992 \\
17,883 \\
840 \\
2,330 \\
41,477\end{array}$ & $\begin{array}{r}12,013 \\
1,001 \\
20,413 \\
1,325 \\
23,294 \\
26,713 \\
3,826 \\
376 \\
88,961\end{array}$ & $\begin{array}{r}14,895 \\
4,426 \\
25,540 \\
4,323 \\
29,283 \\
44,596 \\
4,656 \\
2,706 \\
130,438\end{array}$ & $\begin{array}{r}276 \\
1,145 \\
60 \\
202 \\
1,010 \\
248 \\
51 \\
75 \\
3,067\end{array}$ & $\begin{array}{r}991 \\
320 \\
1,800 \\
207 \\
3,104 \\
423 \\
67 \\
2 \\
6,964\end{array}$ & $\begin{array}{r}315 \\
467 \\
410 \\
111 \\
3,154 \\
4,468 \\
112 \\
304 \\
9,411\end{array}$ & $\begin{array}{r}1,757 \\
558 \\
1,240 \\
377 \\
11,891 \\
15,389 \\
764 \\
227 \\
32,203\end{array}$ & $\begin{array}{r}3,473 \\
5,037 \\
5,597 \\
3,381 \\
10,156 \\
22,599 \\
1,5903 \\
2,709 \\
53,955\end{array}$ & $\begin{array}{r}14,761 \\
1,879 \\
23,503 \\
1,909 \\
38,289 \\
42,5525 \\
4,657 \\
605 \\
128,128\end{array}$ & $\begin{array}{r}18,234 \\
6,916 \\
29,100 \\
5,290 \\
48,45 \\
65,124 \\
5,660 \\
3,314 \\
182,083\end{array}$ \\
\hline \multirow{3}{*}{ gion 3} & \multirow{3}{*}{$\begin{array}{l}\text { De laware } \\
\text { Dist. of } \\
\text { Maryland Col. } \\
\text { Mennsylvania } \\
\text { Virginia } \\
\text { Vest Virginia } \\
\text { Total }\end{array}$} & 0,045 & 1,020 & & , 437 & 1,916 & , 353 & ,218 & , 116 & & 2,084 & 6,848 & 3,249 & 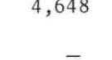 & 3,734 & , 479 , & ,657 & $41,4 / 7$ & 88,961 & 30,438 & 3,067 & 6,964 & 9,411 & 2,203 & 53,955 & 28,128 & 82,083 \\
\hline & & $\begin{array}{l}1,588 \\
6,739 \\
3,626 \\
1,018\end{array}$ & $\begin{array}{c}- \\
- \\
247 \\
526 \\
186\end{array}$ & $\begin{array}{l}1,588 \\
6,986 \\
4,152 \\
1,204\end{array}$ & $\begin{array}{r}319 \\
3,451 \\
2,303 \\
2,342 \\
411\end{array}$ & $\begin{array}{l}172 \\
464 \\
635 \\
584 \\
150\end{array}$ & $\begin{array}{r}494 \\
3,915 \\
2,938 \\
2,936 \\
2,926 \\
561\end{array}$ & $\begin{array}{r}491 \\
5,503 \\
9,924 \\
7,078 \\
1,765\end{array}$ & $\begin{array}{r}1,001 \\
3,794 \\
10,205 \\
5,639 \\
2,436\end{array}$ & $\begin{array}{l}1,012 \\
3,977 \\
8,896 \\
3,528 \\
1,168\end{array}$ & $\begin{array}{r}1,3,072 \\
7,776 \\
19,101 \\
9,1167 \\
3,600\end{array}$ & $\begin{array}{l}2,0 \\
2,019 \\
6,963 \\
4,050 \\
1,676\end{array}$ & $\begin{array}{r}1,-79 \\
4,91 \\
4,997 \\
463 \\
316\end{array}$ & $\begin{array}{r}525 \\
525 \\
635 \\
2,584 \\
1,209\end{array}$ & $\begin{array}{r}570 \\
504 \\
110 \\
125 \\
74\end{array}$ & $\begin{array}{r}570 \\
47,749 \\
12,133 \\
7,1222 \\
3,275\end{array}$ & $\begin{array}{r}1 \overline{171} \\
7,338 \\
3,267 \\
83\end{array}$ & $\begin{array}{r}1,037 \\
7,926 \\
24,217 \\
16,425 \\
6,525\end{array}$ & $\begin{array}{r}2,3133 \\
10,264 \\
24,279 \\
10,309 \\
2,202\end{array}$ & $\begin{array}{r}2,2,134 \\
18,130 \\
48,496 \\
26,734 \\
8,727\end{array}$ & $\begin{array}{r}450 \\
3,783 \\
162 \\
22\end{array}$ & $\begin{array}{r}\overline{7} \\
70 \\
2,683 \\
169 \\
152\end{array}$ & $\begin{array}{r}3,642 \\
2,403 \\
2,306 \\
657\end{array}$ & $\begin{array}{r}197 \\
9,489 \\
2,834 \\
6,337 \\
5,270 \\
1,012\end{array}$ & $\begin{array}{r}12,018 \\
30,403 \\
18,893 \\
7,204\end{array}$ & $\begin{array}{r}3,1,08 \\
13,168 \\
33,299 \\
15,748 \\
3,366\end{array}$ & $\begin{array}{r}3,082 \\
25,186 \\
63,702 \\
34,641 \\
10,570\end{array}$ \\
\hline & & 13,079 & 959 & 14,038 & 9,220 & 2,005 & 11,225 & 25,263 & 23,149 & 19,158 & 42,307 & 15,182 & 7,706 & 4,381 & 1,383 & 28,652 & 11,312 & 56,750 & 50,784 & 107,534 & 4,417 & 3,074 & 9,182 & 16,599 & 70,349 & 70,457 & 140,806 \\
\hline Region 4 & $\begin{array}{l}\text { Alabama } \\
\text { Floridaa } \\
\text { Georgia } \\
\text { Kentucky } \\
\text { Mississippi } \\
\text { North Carolina } \\
\text { South Carolina } \\
\text { Tennessee } \\
\quad \text { Total }\end{array}$ & $\begin{array}{l}1,758 \\
3,444 \\
4,662 \\
2,853 \\
1,469 \\
2,599 \\
2,5622 \\
4,091 \\
23,938\end{array}$ & $\begin{array}{r}627 \\
1,378 \\
813 \\
321 \\
130 \\
692 \\
182 \\
111 \\
4,254\end{array}$ & $\begin{array}{l}2,385 \\
5,322 \\
5,475 \\
3,174 \\
1,599 \\
3,231 \\
2,804 \\
4,202 \\
28,192\end{array}$ & $\begin{array}{r}887 \\
2,961 \\
3,156 \\
1,011 \\
450 \\
1,260 \\
6,18 \\
2,447 \\
12,790\end{array}$ & $\begin{array}{r}-601 \\
1,003 \\
230 \\
566 \\
342 \\
565 \\
28 \\
233 \\
3,608\end{array}$ & $\begin{array}{r}1,488 \\
4,004 \\
3,386 \\
1,577 \\
792 \\
1,825 \\
646 \\
2,680 \\
16,398\end{array}$ & $\begin{array}{l}3,873 \\
9,326 \\
8,861 \\
4,751 \\
2,391 \\
5,056 \\
3,450 \\
6,882 \\
44,590\end{array}$ & $\begin{array}{l}5,198 \\
7,365 \\
7,291 \\
4,947 \\
4,759 \\
6,564 \\
6,223 \\
6,775 \\
49,122\end{array}$ & $\begin{array}{l}3,954 \\
3,604 \\
3,040 \\
2,478 \\
1,053 \\
3,157 \\
3,335 \\
3,998 \\
24,619\end{array}$ & $\begin{array}{r}9,152 \\
10,969 \\
10,331 \\
7,425 \\
5,812 \\
9,721 \\
9,558 \\
10,773 \\
73,741\end{array}$ & $\begin{array}{r}1,949 \\
5,521 \\
3,839 \\
4,479 \\
1,150 \\
11,072 \\
3,497 \\
1,618 \\
33,125\end{array}$ & $\begin{array}{r}388 \\
2,379 \\
473 \\
1,065 \\
109 \\
3,506 \\
1,286 \\
275 \\
9,481\end{array}$ & $\begin{array}{r}1,406 \\
2,087 \\
1,933 \\
264 \\
1,518 \\
17 \\
166 \\
1,218 \\
8,599\end{array}$ & $\begin{array}{r}339 \\
577 \\
487 \\
91 \\
355 \\
21 \\
21 \\
214 \\
210 \\
2,105\end{array}$ & $\begin{array}{r}4,082 \\
10,564 \\
6,732 \\
5,899 \\
3,132 \\
14,1606 \\
4,970 \\
3,325 \\
53,310\end{array}$ & $\begin{array}{r}559 \\
9,968 \\
410 \\
623 \\
1,094 \\
1,094 \\
- \\
1,585 \\
15,333\end{array}$ & $\begin{array}{r}10,938 \\
20,295 \\
18,538 \\
12,864 \\
9,026 \\
20,874 \\
12,690 \\
13,813 \\
119,038\end{array}$ & $\begin{array}{r}6,728 \\
20,532 \\
7,7966 \\
5,834 \\
3,4003 \\
9,003 \\
5,288 \\
8,752 \\
67,936\end{array}$ & $\begin{array}{r}17,666 \\
40,827 \\
26,334 \\
18,698 \\
12,429 \\
30,477 \\
17,978 \\
22,565 \\
186,974\end{array}$ & $\begin{array}{r}46 \\
1,373 \\
96 \\
1,544 \\
10 \\
1,835 \\
435 \\
121 \\
5,460\end{array}$ & $\begin{array}{r}401 \\
1,148 \\
470 \\
698 \\
9 \\
687 \\
1,415 \\
233 \\
5,061\end{array}$ & $\begin{array}{r}1,344 \\
4,117 \\
3,356 \\
1,226 \\
673 \\
246 \\
426 \\
2,770 \\
14,158\end{array}$ & $\begin{array}{r}5,381 \\
14,250 \\
9,016 \\
2,5222 \\
1,237 \\
3,155 \\
349 \\
7,237 \\
43,147\end{array}$ & $\begin{array}{r}12,328 \\
25,785 \\
21,990 \\
15,634 \\
92,709 \\
22,955 \\
13,551 \\
16,704 \\
138,656\end{array}$ & $\begin{array}{r}12,510 \\
35,930 \\
17,282 \\
9,054 \\
4,649 \\
13,445 \\
7,052 \\
16,222 \\
116,144\end{array}$ & $\begin{array}{r}24,838 \\
61,715 \\
39,272 \\
24,688 \\
14,358 \\
36,400 \\
20,603 \\
32,926 \\
254,800\end{array}$ \\
\hline gion 5 & $\begin{array}{l}\text { I11inois } \\
\text { Indiana } \\
\text { Michigan } \\
\text { Minnesota } \\
\text { Ohio } \\
\text { Wisconsin } \\
\quad \text { Total }\end{array}$ & $\begin{array}{l}4,594 \\
4,165 \\
3,75 \\
1,356 \\
6,267 \\
2,144 \\
22,271\end{array}$ & $\begin{array}{r}637 \\
123 \\
168 \\
125 \\
4 \\
136 \\
1,193\end{array}$ & $\begin{array}{r}5,231 \\
4,288 \\
3,903 \\
1,491 \\
6,271 \\
2,280 \\
23,464\end{array}$ & $\begin{array}{r}7,014 \\
2,727 \\
5,712 \\
2,249 \\
8,952 \\
1,1127 \\
27,781\end{array}$ & $\begin{array}{r}438 \\
276 \\
1,176 \\
488 \\
349 \\
243\end{array}$ & $\begin{array}{l}7,452 \\
3,003 \\
6,888 \\
2,737 \\
9,301 \\
1,370 \\
30,751\end{array}$ & $\begin{array}{r}12,683 \\
7,291 \\
10,791 \\
4,228 \\
15,572 \\
3,650 \\
54,215\end{array}$ & $\begin{array}{l}8,522 \\
6,861 \\
7,592 \\
5,615 \\
8,637 \\
6,008 \\
43,235\end{array}$ & $\begin{array}{r}10,524 \\
2,741 \\
6,329 \\
3,162 \\
6,475 \\
3,307 \\
32,538\end{array}$ & $\begin{array}{r}19,046 \\
9,602 \\
13,921 \\
8,777 \\
15,112 \\
9,315 \\
75,773\end{array}$ & $\begin{array}{r}761 \\
3,920 \\
1,843 \\
1,221 \\
6,127 \\
2,222 \\
16,094\end{array}$ & $\begin{array}{r}1,208 \\
1,1109 \\
1192 \\
1177 \\
1,960 \\
47 \\
4,653\end{array}$ & $\begin{array}{r}1,912 \\
1,999 \\
6,550 \\
1,898 \\
2,681 \\
1,854 \\
16,894\end{array}$ & $\begin{array}{r}818 \\
328 \\
70 \\
289 \\
2,575 \\
603 \\
4,683\end{array}$ & $\begin{array}{r}4,699 \\
7,356 \\
8,655 \\
3,545 \\
13,343 \\
4,726 \\
42,324\end{array}$ & $\begin{array}{r}3,864 \\
4,815 \\
16,016 \\
3,763 \\
2,804 \\
3,165 \\
34,427\end{array}$ & $\begin{array}{l}16,426 \\
11,7068 \\
19,888 \\
10,225 \\
23,716 \\
12,364 \\
99,687\end{array}$ & $\begin{array}{r}23,866 \\
11,996 \\
29,495 \\
10,088 \\
23,115 \\
8,492 \\
107,052\end{array}$ & & $\begin{array}{r}1,011 \\
141 \\
29 \\
22 \\
266 \\
76 \\
1,545\end{array}$ & $\begin{array}{r}2,422 \\
100 \\
64 \\
44 \\
370 \\
2 \\
2 \\
3,002\end{array}$ & $\begin{array}{r}2,749 \\
1,391 \\
2,985 \\
1,228 \\
5,546 \\
2,002 \\
15,901\end{array}$ & $\begin{array}{r}14,469 \\
6,663 \\
5,712 \\
4,017 \\
11,121 \\
5,648 \\
47,630\end{array}$ & $\begin{array}{l}20,186 \\
18,600 \\
22,902 \\
11,475 \\
29,528 \\
14,442 \\
117,133\end{array}$ & & $\begin{array}{r}60,943 \\
37,359 \\
58,117 \\
25,624 \\
64,134 \\
28,584 \\
274,817\end{array}$ \\
\hline Region 6 & $\begin{array}{l}\text { Arkansas } \\
\text { Louisiana } \\
\text { New Mexico } \\
\text { Oklahoma } \\
\text { Texas } \\
\text { Tota1 }\end{array}$ & $\begin{array}{r}1,586 \\
1,757 \\
1,813 \\
2,317 \\
7,918 \\
15,391\end{array}$ & $\begin{array}{r}- \\
211 \\
214 \\
- \\
906 \\
1,331\end{array}$ & $\begin{array}{r}1,586 \\
1,968 \\
2,027 \\
2,317 \\
8,824 \\
16,722\end{array}$ & $\begin{array}{r}671 \\
1,378 \\
524 \\
1,341 \\
10,436 \\
14,350\end{array}$ & $\begin{array}{l}- \\
68 \\
90 \\
83 \\
375 \\
616\end{array}$ & $\begin{array}{r}671 \\
1,446 \\
614 \\
1,424 \\
10,811 \\
14,966\end{array}$ & $\begin{array}{r}2,257 \\
3,414 \\
2,641 \\
3,741 \\
.19,635 \\
31,688\end{array}$ & $\begin{array}{l}3,316 \\
3,089 \\
1,928 \\
4,242 \\
12,809 \\
25,384\end{array}$ & $\begin{array}{r}1,434 \\
2,001 \\
780 \\
997 \\
10,464 \\
15,676\end{array}$ & $\begin{array}{r}4,750 \\
5,090 \\
2,708 \\
5,239 \\
23,273 \\
41,060\end{array}$ & $\begin{array}{r}2,878 \\
4,409 \\
1,228 \\
2,817 \\
10,006 \\
21,338\end{array}$ & $\begin{array}{r}559 \\
1,141 \\
96 \\
52 \\
2,083 \\
3,931\end{array}$ & $\begin{array}{c}278 \\
-11 \\
11 \\
568 \\
- \\
857\end{array}$ & $\begin{array}{c}94 \\
- \\
7 \\
44 \\
- \\
145\end{array}$ & $\begin{array}{r}3,809 \\
5,550 \\
1,342 \\
3,481 \\
12,089 \\
26,271\end{array}$ & $\begin{array}{r}701 \\
2,121 \\
1,567 \\
4,972 \\
9,797 \\
19,158\end{array}$ & $\begin{array}{r}8,058 \\
9,466 \\
5,194 \\
9,944 \\
31,639 \\
64,301\end{array}$ & $\begin{array}{r}3,459 \\
6,709 \\
3,064 \\
7,489 \\
33,155 \\
53,876\end{array}$ & $\begin{array}{r}11,517 \\
16,175 \\
8,258 \\
17,433 \\
64,794 \\
118,177\end{array}$ & $\begin{array}{r}100 \\
997 \\
130 \\
386 \\
1,746 \\
3,359\end{array}$ & $\begin{array}{r}71 \\
304 \\
49 \\
31 \\
339 \\
794\end{array}$ & $\begin{array}{l}1,001 \\
1,503 \\
6,17 \\
1,000 \\
3,626 \\
7,837\end{array}$ & $\begin{array}{r}1,254 \\
1,347 \\
3,767 \\
3,784 \\
14,077 \\
21,329\end{array}$ & $\begin{array}{r}9,159 \\
11,966 \\
51,941 \\
11,420 \\
37,011 \\
75,497\end{array}$ & $\begin{array}{r}4,784 \\
8,360 \\
3,90 \\
11,3804 \\
47,557 \\
75,999\end{array}$ & $\begin{array}{r}13,943 \\
20,326 \\
9,921 \\
22,724 \\
84,582 \\
151,496\end{array}$ \\
\hline egion 7 & & & $\begin{array}{r}92 \\
19 \\
307 \\
1\end{array}$ & & $\begin{array}{r}716 \\
746 \\
4,209 \\
380\end{array}$ & $\begin{array}{r}174 \\
52 \\
188 \\
15\end{array}$ & $\begin{array}{r}890 \\
798 \\
4,397 \\
395\end{array}$ & $\begin{array}{l}3,033 \\
2,324 \\
7,834 \\
1,683\end{array}$ & $\begin{array}{l}6,060 \\
4,302 \\
5,768 \\
3,095\end{array}$ & & & $\begin{array}{r}- \\
653 \\
3,797 \\
606\end{array}$ & $\begin{array}{r}- \\
35 \\
924 \\
15\end{array}$ & $\begin{array}{r}2,394 \\
1,560 \\
12 \\
850\end{array}$ & $\begin{array}{r}473 \\
506 \\
12 \\
99\end{array}$ & $\begin{array}{l}2,867 \\
2,754 \\
4,745 \\
1,570\end{array}$ & & $\begin{array}{r}10,597 \\
8,041 \\
13,014 \\
5,839\end{array}$ & & & $\begin{array}{r}100 \\
61 \\
45 \\
5\end{array}$ & $\begin{array}{c}165 \\
34 \\
213 \\
-\end{array}$ & $\begin{array}{r}949 \\
1,226 \\
1,839 \\
684\end{array}$ & & & & $\begin{array}{l}19,633 \\
15,485 \\
30,675 \\
11,211\end{array}$ \\
\hline & Total & 7,975 & 419 & 8,394 & 6,051 & 429 & 6,480 & 14,874 & 19,225 & 6,289 & 25,514 & 5,056 & 974 & 4,816 & 1,090 & 11,936 & 6,250 & 37,491 & 21,083 & 58,574 & 211 & 412 & 4,698 & 13,109 & 42,400 & 34,604 & 77,004 \\
\hline egion 8 & $\begin{array}{l}\text { Colorado } \\
\text { Montana } \\
\text { North Dakota } \\
\text { South Dakota } \\
\text { Utah } \\
\text { Wyoming } \\
\text { Total }\end{array}$ & $\begin{array}{r}1,902 \\
784 \\
614 \\
888 \\
1,086 \\
1,070\end{array}$ & $\begin{array}{r}255 \\
333 \\
30 \\
134 \\
337 \\
96\end{array}$ & $\begin{array}{r}2,157 \\
1,117 \\
644 \\
992 \\
1,423 \\
1,166 \\
7,160\end{array}$ & $\begin{array}{r}1,382 \\
67 \\
49 \\
40 \\
40 \\
1,093 \\
40 \\
2,671\end{array}$ & $\begin{array}{c}- \\
- \\
3 \\
5 \\
27 \\
8\end{array}$ & $\begin{array}{r}1,382 \\
67 \\
52 \\
45 \\
1,120 \\
48\end{array}$ & $\begin{array}{l}3,539 \\
1,184 \\
6696 \\
1,037 \\
2,543 \\
1,214\end{array}$ & $\begin{array}{l}2,912 \\
1,673 \\
1,424 \\
1,739 \\
1,007 \\
1,093 \\
9,848\end{array}$ & $\begin{array}{r}2,170 \\
260 \\
265 \\
311 \\
215 \\
94\end{array}$ & $\begin{array}{l}5,082 \\
1,933 \\
1,689 \\
2,050 \\
1,222 \\
1,187\end{array}$ & $\begin{array}{r}1,427 \\
- \\
289 \\
300 \\
531 \\
281\end{array}$ & $\begin{array}{c}350 \\
- \\
-3 \\
-142 \\
-\end{array}$ & $\begin{array}{l}- \\
471 \\
518 \\
479 \\
135 \\
16\end{array}$ & $\begin{array}{l}- \\
\overline{24} \\
\overline{39}\end{array}$ & $\begin{array}{r}1,777 \\
471 \\
834 \\
779 \\
847 \\
297\end{array}$ & $\begin{array}{r}1,924 \\
434 \\
276 \\
356 \\
2,126 \\
242\end{array}$ & $\begin{array}{r}6,496 \\
3,261 \\
2,875 \\
3,510 \\
3,006 \\
2,556 \\
21,794\end{array}$ & $\begin{array}{r}5,826 \\
761 \\
620 \\
712 \\
3,642 \\
384\end{array}$ & & $\begin{array}{c}22 \\
-1 \\
27 \\
31 \\
5\end{array}$ & $\begin{array}{r}38 \\
- \\
2 \\
2 \\
11 \\
1\end{array}$ & $\begin{array}{r}1,777 \\
1,076 \\
715 \\
512 \\
500 \\
390 \\
4,970\end{array}$ & $\begin{array}{r}2,438 \\
225 \\
289 \\
297 \\
662 \\
346\end{array}$ & $\begin{array}{l}8,295 \\
4,337 \\
3,591 \\
4,049 \\
3,627 \\
2,951 \\
26,950\end{array}$ & & $\begin{array}{r}16,597 \\
5,723 \\
4,502 \\
5,060 \\
7,942 \\
3,682\end{array}$ \\
\hline egion 9 & & $\begin{array}{r}2,328 \\
6,596 \\
91 \\
803\end{array}$ & $\begin{array}{r}578 \\
1,027 \\
103 \\
123\end{array}$ & $\begin{array}{r}2,906 \\
7,623 \\
194 \\
926\end{array}$ & $\begin{array}{r}564 \\
18,927 \\
429 \\
164\end{array}$ & $\begin{array}{r}184 \\
3,154 \\
176 \\
10\end{array}$ & $\begin{array}{r}748 \\
22,081 \\
605 \\
174\end{array}$ & $\begin{array}{r}3,3654 \\
29,704 \\
799 \\
1,100\end{array}$ & $\begin{array}{r}1,964 \\
11,602 \\
990 \\
795\end{array}$ & $\begin{array}{r}563 \\
20,770 \\
605 \\
328\end{array}$ & & $\begin{array}{r}715 \\
2,891 \\
2844 \\
380\end{array}$ & $\begin{array}{c}43 \\
350 \\
53 \\
60\end{array}$ & $\begin{array}{r}838 \\
4,053 \\
68 \\
126\end{array}$ & $\begin{array}{r}333 \\
1,067 \\
67 \\
96\end{array}$ & $\begin{array}{r}1,929 \\
8,361 \\
432 \\
662\end{array}$ & $\begin{array}{r}4,747 \\
35,541 \\
558 \\
435\end{array}$ & $\begin{array}{r}6,423 \\
26,169 \\
1,456 \\
2,227\end{array}$ & & & $\begin{array}{r}387 \\
236 \\
16 \\
31\end{array}$ & $\begin{array}{r}6 \\
129 \\
- \\
21\end{array}$ & $\begin{array}{r}711 \\
11,391 \\
290 \\
189\end{array}$ & $\begin{array}{r}2,022 \\
14,866 \\
486 \\
878\end{array}$ & $\begin{array}{r}7,521 \\
37,796 \\
1,762 \\
2,447\end{array}$ & $\begin{array}{r}8,462 \\
94,804 \\
2,384 \\
1,992\end{array}$ & $\begin{array}{r}15,983 \\
132,600 \\
4,146 \\
4,439\end{array}$ \\
\hline & Total & 9,818 & 1,831 & 11,649 & 20,084 & 3,524 & 23,608 & 35,257 & 15,311 & 22,266 & 37,577 & 4,230 & 506 & 5,085 & 1,563 & 11,384 & 41,291 & 36,275 & 89,234 & 125,509 & 670 & 156 & 12,581 & 18,252 & 49,526 & 107,642 & 157,168 \\
\hline & $\begin{array}{l}\text { Alaska } \\
\text { Idaho } \\
\text { Oregon } \\
\text { Washington }\end{array}$ & $\begin{array}{r}- \\
937 \\
2,072 \\
1,332\end{array}$ & $\begin{array}{l}-\overline{174} \\
38 \\
764\end{array}$ & $\begin{array}{r}\tilde{1}, 111 \\
2,110 \\
2,096\end{array}$ & $\begin{array}{r}-\overline{154} \\
1,235 \\
3,452\end{array}$ & $\begin{array}{r}- \\
10 \\
121 \\
222\end{array}$ & $\begin{array}{r}- \\
164 \\
1,356 \\
3,674\end{array}$ & $\begin{array}{l}- \\
1,275 \\
3,466 \\
5,770\end{array}$ & $\begin{array}{r}816 \\
1,327 \\
2,7922 \\
3,187\end{array}$ & $\begin{array}{r}403 \\
185 \\
1,522 \\
2,152\end{array}$ & $\begin{array}{l}1,219 \\
1,512 \\
4,314 \\
5,339\end{array}$ & $\begin{array}{r}307 \\
607 \\
1,229 \\
1,248\end{array}$ & $\begin{array}{r}68 \\
30 \\
143 \\
850\end{array}$ & $\begin{array}{r}- \\
427 \\
1,115 \\
1,728\end{array}$ & $\begin{array}{r}- \\
23 \\
996 \\
1,054\end{array}$ & $\begin{array}{r}375 \\
1,147 \\
3,319 \\
4,880\end{array}$ & $\begin{array}{r}\overline{682} \\
\overrightarrow{1,686}\end{array}$ & $\begin{array}{l}1,123 \\
3,532 \\
7,2282 \\
8,259\end{array}$ & & & $\begin{array}{l}- \\
6 \\
52 \\
21\end{array}$ & $\begin{array}{l}- \\
60 \\
5\end{array}$ & $\begin{array}{r}475 \\
513 \\
3,172 \\
1,920\end{array}$ & & & & $\begin{array}{r}2,5,50 \\
5,873 \\
15,938 \\
24,023\end{array}$ \\
\hline & Total & 4,341 & 976 & 5,317 & 4,841 & 353 & 5,194 & 10,511 & 8,122 & 4,262 & 12,384 & 3,451 & 1,091 & 3,306 & 1,873 & 9,721 & 2,368 & 20,196 & 14,788 & 34,984 & 79 & 65 & 6,080 & 7,186 & 26,355 & 22,039 & 48,394 \\
\hline & U.S. Tota1 & 111,972 & 13,168 & 125,140 & 8,225 & 15,464 & 133,689 & 258,829 & 213,512 & 0,091 & 373,603 & 8,152 & 32,086 & 50,205 & 16,639 & 207,082 & 163,154 & 497,009 & 505,659 & $1,002,668$ & 18,894 & 19,582 & 84,818 & 204,112 & 600,721 & 729,353 & , 330,074 \\
\hline
\end{tabular}

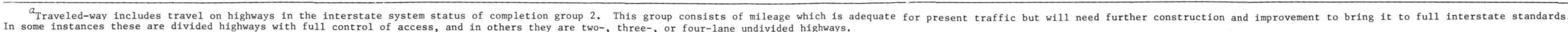

${ }^{5}$ Travel on Delaware's interstate traveled-way is included in the figure for interstate urban final.

Source: - U.S. Department of Transportation, Federal Highway Administration, Highway Statistics, Washington, D.C., annual, Table VM-2. 


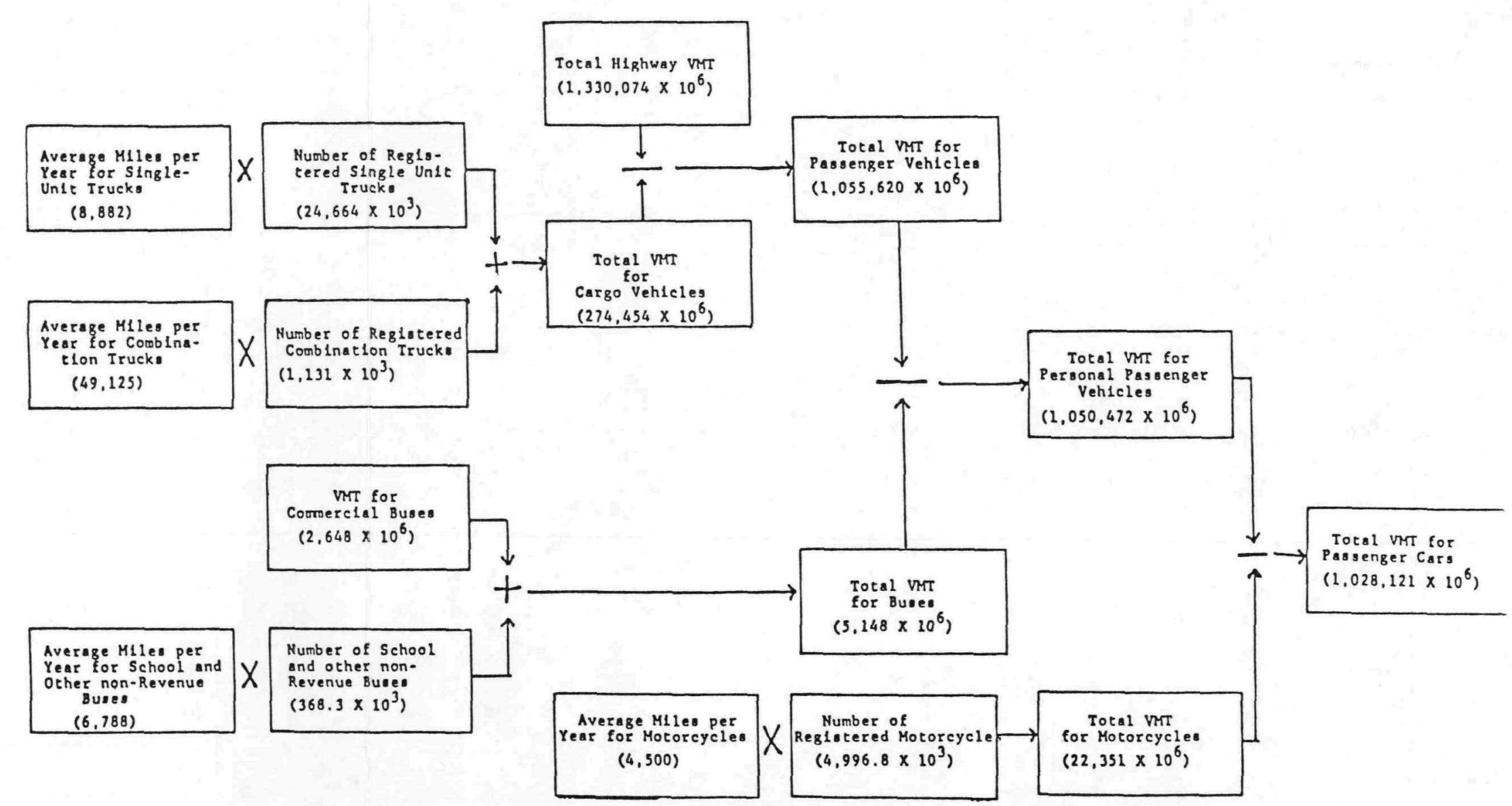

Fig. 2. Schematic Representation of the FHWA Approach by Use of 1975 Data. (Numbers are for 1975 and are taken from FHWA's Table VM-1 reproduced as Table 1.)

Source: TERA, Inc., Existing Data on Vehicle-Miles Traveled in the United States, July 1977, Fig. 2, p. 11. 
Some of the intermittent values are developed from analyzing annual trends; in other years, current values are empirically derived. In either case, FHWA preparation of VMT data is an iterative process.

Although the total VMT for passenger cars reported by the FHWA is a derived figure, the final VMT estimate for passenger cars is checked by FHWA against data from other sources (Table 3). Depending upon the year of survey, sample size, and geographic scope, average annual-miles per car range from 8,840 to 11,800 miles. Average annual-miles differ from one source to another by as much as $33.5 \%$. The differences largely come from differences in geographic scope, survey year, and sample size; therefore, a comparison is meaningless. Even when the year of survey, sample size, and geographic scope are similar, the average annual-miles differ by $14 \%$.

An often misunderstood discrepancy in comparing average-miles-perautomobile data obtained from household surveys with similar FHWA data stems from the difference in the data base used. For example, average annual-miles per car reported in the 1969-70 Nationwide Personal Transportation Study (NPTS) is 11,600 miles, whereas FHWA reported 9,782 miles for 1969 (Table 1). The NPTS data is from home interviews while the FHWA value is total miles of auto travel divided by the number of vehicles registered during the same year. Other sampling variations and biases may cause additional (but smaller) differences.

\section{1 .2 State approach}

FHWA and all state DOTs use a uniform format to report VMT data to FHWA annually, but no uniform method is used by all states to generate or compile VMT data. The FHWA is currently developing a uniform computational method based on the Claffey analysis. ${ }^{3}$ The method is a computerized algorithm (RDTRAV) estimating travel on nonfederal-aid roads where counts are not available. Claffey's method has two steps: First, a base table showing average fuel use by vehicle type and by highway operating conditions is prepared. Next, the base table 
Table 3. Average Annua1-Miles Traveled Per Car - Results of Nine Surveys

\begin{tabular}{|c|c|c|c|c|c|c|c|c|c|}
\hline & $\begin{array}{l}\text { Wash. Center } \\
\text { for Metro. } \\
\text { Studies }\end{array}$ & $\begin{array}{l}\text { Univ. of Mich. } \\
\text { Hwy. Safety } \\
\text { Institute }\end{array}$ & $\begin{array}{l}\text { N.Y. State } \\
\text { Dept. of } \\
\text { Motor Veh }\end{array}$ & $\begin{array}{l}\text { Univ. of N.C. } \\
\text { Hwy. Safety } \\
\text { Res. Center }\end{array}$ & $\begin{array}{l}\text { Unıv. of Cal. } \\
\text { Inst. for Transp. } \\
\text { \& Traffic } \\
\text { Engineering }\end{array}$ & $\begin{array}{c}\text { Nationwide } \\
\text { Pers. Transp } \\
\text { Study }\end{array}$ & $\begin{array}{l}\text { Survey of } \\
\text { and Purchases } \\
\text { Ownership }\end{array}$ & $\begin{array}{l}\text { Arthur D. } \\
\text { Little, } \\
\text { Inc. }\end{array}$ & $\begin{array}{l}\text { U.S. News } \\
\text { and World } \\
\text { Report }\end{array}$ \\
\hline $\begin{array}{l}\text { Average annual- } \\
\text { miles per car }\end{array}$ & 9,140 & 10,210 & 11,100 & 8,840 & 11,800 & 11,600 & 11,800 & 16,828 & 9,900 \\
\hline Year of survey & 1973 & 1970 & 1971 & 1968 & 1970 & $1969-70$ & 1974 & 1976 & 1976 \\
\hline $\begin{array}{l}\text { Sample size } \\
\text { (number of } \\
\text { households) }\end{array}$ & 1,450 & 8,000 & $a$ & $47,000^{b}$ & 8,900 & 6,000 & 15,000 & $700^{c}$ & $11,707^{d}$ \\
\hline $\begin{array}{l}\text { Geographic } \\
\text { scope }\end{array}$ & National & National & New York & $\begin{array}{l}\text { North } \\
\text { Carolina }\end{array}$ & Calıforma & National & National & National & National \\
\hline
\end{tabular}

$a_{\text {Not }}$ reported.

$b_{\text {Number of vehicles. }}$

${ }^{c}$ National sample of new car buyers.

The sample for this mall study was selected on a national cross-sectional basis from lists maintained by the Reuben $H$. Donnelley Corporation, with heavy oversampling in the higher income households which control most of the buylng activity in selective consumer markets. The findings
are based on returns from 11,707 household heads and are projectable to the approximately 65 million households on the Donnelley lists.

Sources: Working Paper 1216-6. "Useful Information for Estımatıng the Transportation Inpacts of Gasolıne Price Increases," the Urban

Institute, Washington, D.C., March 1976.

1973 and 1974 Survey of Purchases and Ownership, Bureau of the Census, U.S. Department of Commerce, 1976

Study of Automobile Dynomics, Arthur D. L1ttle, Inc., 1976

"The Study of American Markets. Automobile Markets," U.S. News and World Report, 1976, p. 68. 
values are combined to compute average statewide fuel use. Twenty-four fuel use averages are condensed into four fuel use averages which are then combined into one statewide average based on proportional travel by vehicle type.

\section{1 .3 TERA approach}

The total VMT for 1975 is first divided into passenger and freight categories. The TERA VMT estimate for passenger transportation (Fig. 1) is higher than the FHWA VMT estimate (Table 1). The difference is TERA's estimate for personal transportation by trucks.

State and local government: Annual VMT is estimated by TERA from the number of publicly owned vehicles reported by FHWA (Table 1). The average annual-miles for state and local government vehicles are assumed to be not significantly different from those of all other vehicles.

Bus: The total bus VMT computed above is in agreement with the FHWA estimate (Table 1). The total for school and other nonrevenue buses is in agreement with the sum of nongovernment school buses and the federal, state, and local government VMT estimates. The sum of nongovernment intercity and intracity VMT estimates agrees with FHWA's commercial bus VMT estimates.

Personal transportation by trucks: TERA explicitly puts trucks used in passenger transportation in the passenger category. The weakness

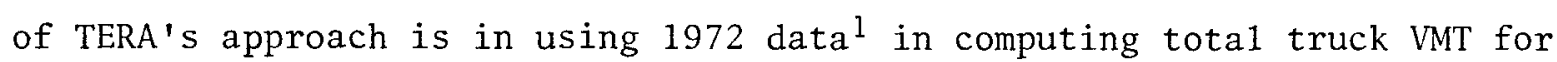
1975. No more recent data is available on personal transportation by trucks. 
Automobile: The only breakdown of automobile VMT beyond the categorization outlined above is taxi VMT.

In the freight category of TERA's highway VMT statistics, the same institutional subdivisions (as in the passenger category) have been used. Truck freight VMT is the difference between total cargo vehicle VMT (Table 1) and total federal, state, and local government VMT and personal truck VMT. Commercial truck VMT is given in single-units and tractor-trailer combinations. A further split is between rural roads and urban streets (Table 1). This distinction is especially important because of problems associated with freight transportation.

\subsection{Rail VMT data}

Rail VMT data are subdivided into freight and passenger with the passenger category divided into local transit and intercity rail (Fig. 1).

\section{2 .1 Rail passenger VMT}

Local transit: The source for VMT data is the American Public Transit Association. The local transit category includes light and heavy rail transit carriers (i.e., subways, streetcars, cable cars, and inclined plane). The total VMT for local transit operations in 1975, broken down into light and heavy rail, is 24 and 423 million miles respectively. ${ }^{4}$

Intercity passenger transportation by rail: This includes passenger train VMT as reported by Class I railroads to the ICC. There were 52 reporting Class I line-hauled railroads as of the end of 1975, and they represent about $99 \%$ of the railroad industry. Class II railroads have operating revenues of less than 10 million dollars per year.

It is important to distinguish between locomotive unit-miles and train-miles. The vehicle which requires power is the locomotive, not the train. In many instances, the motive power used in a train is provided by two or more locomotives. It is TERA's suggestion that locomotive unit-miles be taken as the accurate representation of VMT data in rail operations. (Locomotive unit-miles are not yet 
available for 1975.) To estimate locomotive unit-miles for 1975 for intercity passenger transportation, TERA applied the relationship between train-miles and locomotive unit-miles for 1974 to the 1975 train-miles data.

\subsubsection{Rai1 freight VMT}

Arguments for intercity passenger transportation by rail are equally applicable to freight VMT data.

\subsection{Air VMT data}

\subsubsection{General aviation}

FAA obtains data on hours flown on a voluntary basis and publishes VMT data annually. About $60 \%$ of the forms returned to FAA provide information on hours flown.

\section{3 .2 Air carriers}

VMT data on certified route air carriers and supplemental carriers are compiled and published monthly by the CAB. The VMT data reported by $C A B$ underestimate the total miles flown since these data are airport-toairport distances which do not allow for circling and taxiing.

\subsection{Recommendations}

\subsubsection{Suggested sources to update VMT data}

Only one source for each type of transportation annually compiles and reports VMT statistics (footnotes, Table 1). It is recommended that survey results which appear irregularly be used as a cross reference to check against published statistics.

Vehicle-miles-traveled links energy input to the transportation sector and its outputs. Full and accurate measurements of vehicle fuel efficiencies in themselves do not provide a sufficient basis for 
analyzing the impacts of energy conservation programs upon the nation's transportation system. However, if VMT data are properly linked to transportation outputs such as passenger-miles, ton-miles, number of passsengers, and total tons the data would be adequate. Vehicle use patterns such as load factors and empty backhaul ratio are important determinants of energy efficiency in transportation.

\subsubsection{Improvements in VMT data}

The scope and accuracy of the exisitng VMT data leave much to be desired. Highway VMT constitutes more than $99 \%$ of the total transportation VMT. Highway passenger transportation, which constitutes $88 \%$ of highway VMT, needs the greatest care in compiling VMT statistics. Within the highway passenger transportation category, $87 \%$ is concentrated in personal transportation in passenger cars. The Department of Transportation is continually evaluating and improving the accuracy of VMT statistics. Currently, both FHWA and the Transportation Systems Center (Cambridge, Mass.) are doing VMT research. One possibility being evaluated is the collection of vehicle odometer readings through the state annual vehicle license renewal procedure. One limitation of the existing VMT data is that it is not collected and reported in the detail needed. Available transportation data cover only road, rail, and air transport; water VMT and pipeline (ton-miles) transportation should be included in future compilations.

\subsection{Lifetime VMT}

A better definition of LVMT is needed. Also needed is an improved definition of average retirement age, fleet distribution by vehicle age, and vehicle retirement percentages. In addition, state inputs to the FHWA annual VMT statistics need more study. No record presently exists which explains the approaches used by individual states to generate VMT estimates. Such information is basic in evaluating the validity of FHWA's VMT statistics. 
Lifetime VMT (LVMT) is the sum of average annual-miles traveled by a vehicle in its lifetime. Average annual-miles, as well as vehicle lifespan, vary from year-to-year (Table 4).

Table 4. Lifetime Data for Passenger Cars ${ }^{\alpha}$

\begin{tabular}{crccc}
\hline $\begin{array}{c}\text { Retirement } \\
\text { year }\end{array}$ & \multicolumn{2}{c}{$\begin{array}{c}\text { Average age } \\
\text { at retirement }(y) \\
\text { cars }\end{array}$} & trucks & \multicolumn{2}{c}{$\begin{array}{c}\text { Average } \text { LVMT }^{b} \\
\text { (miles) } \\
\text { cars }\end{array}$} & trucks \\
\hline 1967 & 10.4 & 12.0 & 94,700 & 122,400 \\
1968 & 10.7 & 12.2 & 97,300 & 124,100 \\
1969 & 10.6 & 12.1 & 97,000 & 126,900 \\
1970 & 9.3 & 11.9 & 87,500 & 122,300 \\
1971 & 10.5 & 11.6 & 94,600 & 123,100 \\
1972 & 9.8 & 12.4 & 92,500 & 129,600 \\
1973 & 9.5 & 11.7 & 90,900 & 123,800 \\
1974 & 9.9 & 12.4 & 95,000 & 132,000 \\
1975 & 10.2 & 12.3 & 97,000 & 131,400 \\
1976 & 9.7 & 11.5 & 93,700 & 125,500 \\
\hline
\end{tabular}

$a_{\text {For }} 1961-1976$.

Estimated.

Source: TERA, Inc., Lifetime VMT and Current State Practices to Estimate VMT, October 1977, pp. 29 (Table 8) and 31 (Table 9).

\subsection{LVMT for trucks}

The method used by TERA to estimate LVMT for all trucks retiring in a given year uses three kinds of information in a four-step process (Fig. 3). The three kinds of information used are:

1. mode1-age distribution in the fleet,

2. average annual-miles for all trucks by year, and

3 . average annual-miles by age groups of trucks.

The number of trucks retired was estimated by various age groupings. The ratio of average annual-miles traveled by a certain age group of trucks to the average annual-miles traveled by all trucks in a given year 


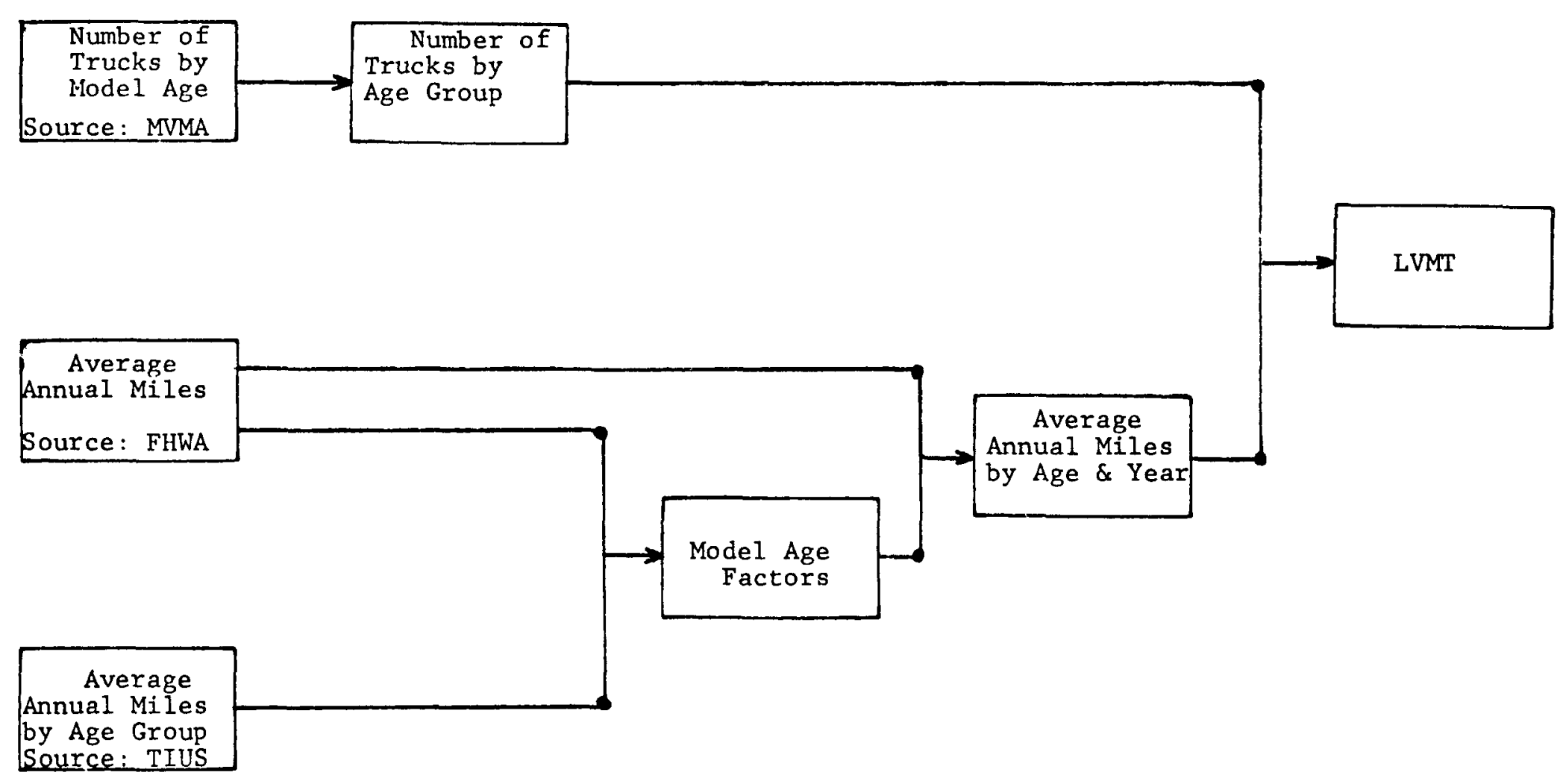

Fig. 3. Method of estimating LVMT for trucks.

Source: TERA, Inc., Lifetime VMT and Current State Practices to Estimate VMT, October 1977, Fig. 1, p. 5. 
was applied to the average annual-miles for all trucks by year to give an estimate of average annual-miles for each calendar year and model year (for the last $10 \mathrm{y}$ ).

The LVMT for trucks retired in a given year was estimated by applying the average annual mileage to the number of trucks retired each year by model year. One assumption must be made: trucks which continue to be in operation after ten years of service continue to $\log$ as many miles in each subsequent year as they do in their tenth year.

\subsubsection{Further concepts and findings}

- Fleet mix - As the size of each year's truck fleet is growing, the fleet is also becoming younger. While $33 \%$ of all trucks in operation were five years old or less in 1960, over 45\% were in 1975-76.

- Average age at retirement - By multiplying the number of retiring trucks from each model year by the model age and then dividing the sum of the products by the sum of all retired trucks in a given year, an average age at retirement for all trucks in a given year can be computed.

- Retirement percentages by model year and calendar year - Average retirement percentages for all two-year-old models can be compared to individual model years. Durability appears to be improving slightly over a ten-year period, at least as measured through the first five years of model's lifetime. The average age of retirement for trucks shows a slight increase durjng the 1961-1971 period. Another possibility is that the differences in these retirement percentages may merely be a reflection of consumer tastes or macroeconomic conditions. The best estimate of LVMT is the actual odometer readings at junk yards.

\subsubsection{Preliminary findings and observations}

- Average retirement age of trucks is a more significant determinant of LVMT than the average annual vehicle-miles.

- From 1967 to 1976, there was an increasing trend in LVMT for trucks, but the increase is not statistically significant, and therefore, it cannot be concluded that the trucks are being made more durable. The 
retirement of trucks within the first five years of service appears to be declining. However, overall LVMT has been increasing in a statistically significant manner.

- Retirement percentages by mode1 year is a high1y appropriate indicator of truck durability among model years.

- The mix of trucks in the national fleet by size did not appreciably change from 1967 to 1972. Whereas heavy-heavy trucks constituted 7.4\% of total truck mileage in 1967, their share in 1972 was $21.3 \%$. This is compensated by a reduction in the share of light trucks (from $73.7 \%$ to $63.2 \%$ ) which could conceivably be attributed to the increase use of light trucks for recreational and/or personal use.

\subsection{LVMT for passenger cars}

\subsubsection{Method}

The method used to complete the LVMT estimate is identical to that used in obtaining the truck LVMT estimates. Three kinds of data are required:

- Model-age distribution in the passenger car fleet mix.

- Average annual-miles traveled for all passenger cars by year.

- Average annual-miles by age group of passenger cars.

First, the number of passenger cars retired was estimated by various age groupings. The second step was the computation of model-age factors. The NPTS made estimates for average annual-miles for each year of a vehicle's lifetime up to ten years in 1969. The 1972 NPTS report was the first time any estimates of miles by vehicle age had been made. The third step was the application of the model-age factors to average annual-miles to estimate average annual-miles for each year by model year. No estimates were made beyond the eleventh year of the car's operation.

These yearly estimates include vehicles which retired with up to 15 years of service or with as few as two. 


\subsubsection{Further concepts and findings}

- Fleet mix - Each year the passenger car fleet is increasing over $3 \%$ while the percentage of vehicles five years old or less has remained fairly constant between 45 and $50 \%$.

- Average age at retirement - The average age of all passenger cars retiring in a given year can be calculated using Motor Vehicle Manufacturers' Association data. The same method can be used for trucks.

- Retirement percentages by model year and calendar year - A clear trend is apparent for passenger cars, but not for trucks.

\section{7 .3 Findings}

- The average retirement age more significantly affected the LVMT of passenger cars than did average annual vehicle-miles.

- As with trucks, no trend in durability of passenger cars is evident.

- As with trucks, retirement percentages by mode1 year give a measure of durability among different model-year passenger cars.

- If average annual-miles continue to increase while LVMT stays constant or declines, then the average retirement age must fall. Alternatively, if average annual-miles increases and LVMT does also, then the average retirement age may increase or remain constant. In any case, increases in vehicle production must equal or be less than the increases in the overall fleet size.

- The implications concerning fuel use efficiency and energy conservation from these last observations are interesting. Where average annual-miles increases and LVMT decreases or remains constant, the overall mpg estimate will improve along with the above-mentioned trend toward a younger, more fuel-efficient fleet. The fleet which becomes increasingly younger will further reinforce the increasing mpg improvement by decreasing the number of less-fuel-efficient vehicles. As long as increases in total VMT per year and increases in mpg are proportional, energy needs for passenger cars could conceivably remain constant. If mpg increases were greater than VMT increases, fuel use by passengers cars would actually decrease. 
If LVMT increases in the future, then conceivably the mpg improvements and the overall goal for energy conservation could be thwarted or deterred. Fuel efficiency and energy conservation goals appear incompatible with improved LVMT and vehicle durability and increasing auto sales. 


\section{CURRENT STATE PRACTICES TO ESTIMATE VMT}

\subsection{Introduction}

The fifty states and the District of Columbia use different methods for compiling and annually reporting highway VMT data to the FHWA. As a preliminary task, data from 1971 through 1975 were obtained from the FHWA for three indicators with a direct relationship to VMT: average mpg, average annual-miles per vehicle, and average miles per household (Tables 4-5). Highway Statistics, published by FHWA annually since 1966, presents statistics reported by individual states. Average mpg is calculated from fuel use and VMT (Table 5). This average mpg is a composite figure for all vehicles (except motorcycles) registered in the state, privately and publicly owned. Average annual-miles per vehicle (Table 6) is derived from Table VM-2 and Table MV-1, State Motor-Vehicle Registrations (published annually). In cases where states are unable to provide actual registration data for some years, FHWA makes its own estimates. Also, data for motor vehicles owned and operated by the military services are not included. The third set of data, annual-miles per household by states (Table 7), is calculated from Table VM-2 and Bureau of the Census data.

Some trends and some changes are contrary to the national trend or a particular state's trend (Tables 5-7). In most cases, average annualmiles per vehicle and annual-miles per household showed a marked decrease in 1974 as a result of the oil embargo. In general, the mpg values vary only slightly from year to year. In only one case was a yearly change greater than $10 \%$. In general the statistics for average annual miles per vehicle, per household, and per gallon exhibit fairly consistent patterns of change from year to year. The reporting of VMT data to FHWA has been a part of the state traffic accident reporting system.

Until recently, the importance of VMT has generally been in areas not related to energy conservation of fuel efficiency - areas such as traffic density, highway safety, and other nonenergy related areas. Only recently have the states increased their interest in accurately estimating VMT data for purposes of energy-related issues. Many states 
Table 5. 1971-75 Average Miles per Gallon and Percent Change by State (Total Vehicle-Miles per Gallon of Highway Motor Fuel Consumed)

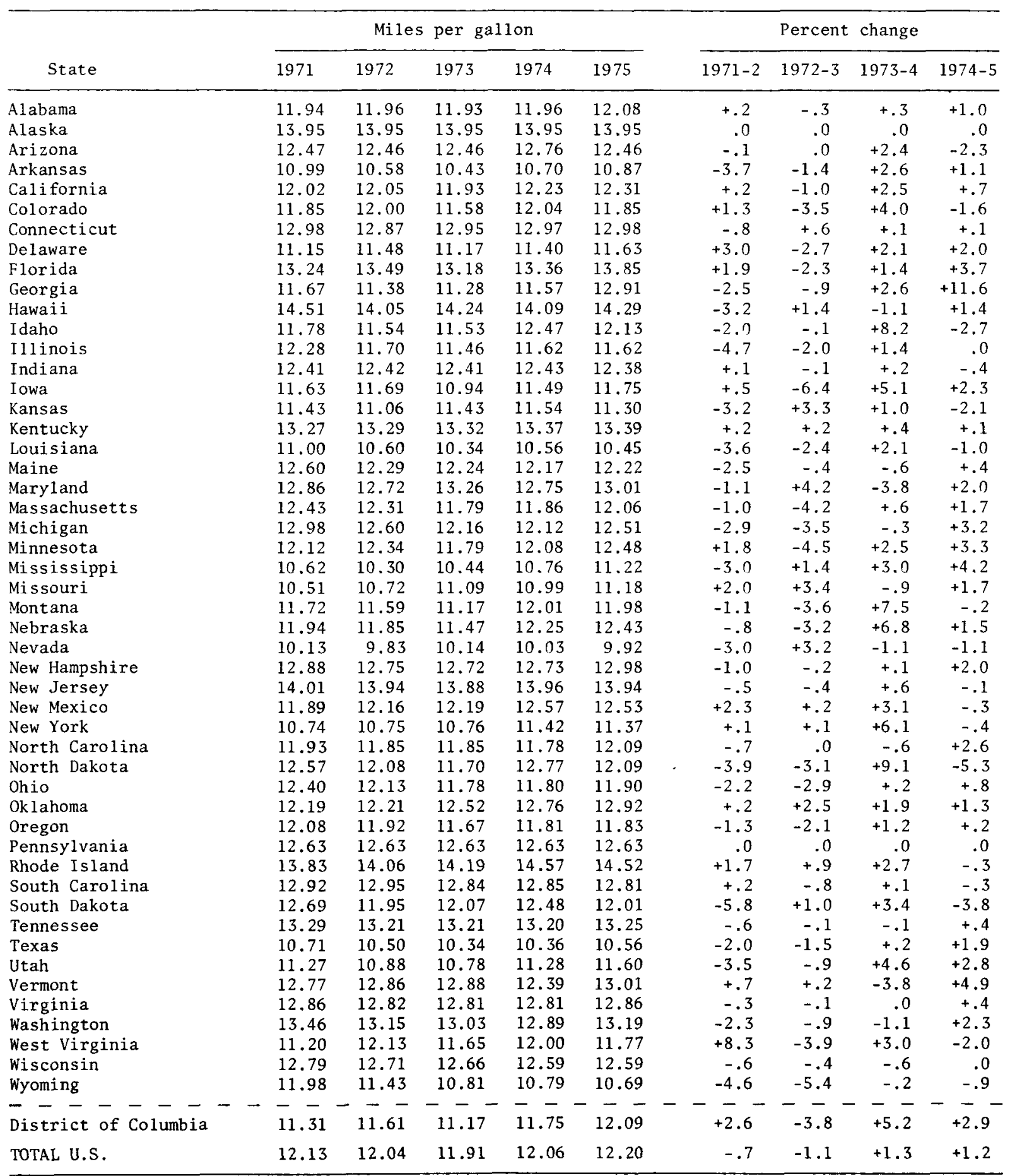

Sources: All values calculated from Table MF-223, Highway Use of Motor Euel, by States, and I'able VM-2, Vehicle Miles by State and Highway System, Highway Statistics, Federal Highway Administration, U.S. Department of Transportation. 
Table 6. 1971-75 Average Annual-Miles per Vehicle and Percent Change by State

\begin{tabular}{|c|c|c|c|c|c|c|c|c|c|}
\hline \multirow[b]{2}{*}{ State } & \multicolumn{5}{|c|}{ Average annual miles } & \multicolumn{4}{|c|}{ Percent change } \\
\hline & 1971 & 1972 & 1973 & 1974 & 1975 & $1971-2$ & $1972-3$ & 1973-4 & $1974-5$ \\
\hline Alabama & 10,112 & 10,208 & 10,230 & 9,927 & 9,964 & .9 & .2 & -3.0 & .4 \\
\hline Alaska & 9,751 & 10,272 & 9,456 & 10,821 & 11,349 & 5.3 & -7.9 & 14.4 & 4.9 \\
\hline Arizona & 11,169 & 11,354 & 11,426 & 10,642 & 10,951 & 1.6 & .6 & -6.9 & 2.9 \\
\hline Arkansas & 11,474 & 11,646 & 11,316 & 10,851 & 10,865 & 1.5 & -2.8 & -4.1 & .1 \\
\hline California & 9,543 & 9,842 & 9,681 & 9,324 & 9,546 & 3.1 & -1.6 & -3.7 & 2.4 \\
\hline Colorado & 9,216 & 9,458 & 8,993 & 8,676 & 8,621 & 2.6 & -4.9 & -3.5 & -.6 \\
\hline Connecticut & 9,559 & 9,566 & 9,448 & 9,041 & 9,354 & .1 & -1.2 & -4.3 & 3.5 \\
\hline De laware & 10,116 & 10,605 & 10,629 & 10,107 & 10,328 & 4.8 & .2 & -4.9 & 2.2 \\
\hline Florida & 10,470 & 11,288 & 11,083 & 10,332 & 11,438 & 7.8 & -1.8 & -6.8 & 10.7 \\
\hline Georgia & 11,424 & 11,260 & 11,153 & 10,820 & 12,231 & -1.4 & -1.0 & -3.0 & 13.0 \\
\hline Hawaii & 8,578 & 8,400 & 8,493 & 8,077 & 8,974 & -2.1 & 1.1 & -4.9 & 11.1 \\
\hline Idaho & 9,682 & 9,586 & 9,244 & 8,935 & 9,071 & -1.0 & -3.6 & -3.3 & 1.5 \\
\hline Illinois & 10,594 & 10,522 & 10,210 & 9,591 & 9,607 & -.7 & -3.0 & -6.1 & .2 \\
\hline Indiana & 11,957 & 12,004 & 11,981 & 11,318 & 11,268 & .4 & -.2 & -5.5 & -.4 \\
\hline Iowa & 9,693 & 9,846 & 9,832 & 9,344 & 9,352 & 1.6 & -.1 & -5.0 & .1 \\
\hline Kansas & 8,669 & 8,686 & 8,663 & 8,517 & 8,508 & .2 & -.3 & -1.7 & .7 \\
\hline Kentucky & 11,559 & 11,689 & 11,668 & 11,003 & 10,996 & 1.1 & -.2 & -5.7 & -.1 \\
\hline Louisiana & 9,614 & 9,607 & 9,391 & 9,157 & 9,292 & -.1 & -2.2 & -2.5 & 1.5 \\
\hline Maine & 11,987 & 11,861 & 11,621 & 10,536 & 10,671 & -1.0 & -2.0 & -9.3 & 1.3 \\
\hline Maryland & 11,091 & 11,092 & 11,308 & 10,186 & 10,396 & 0.0 & 2.0 & -9.9 & 2.1 \\
\hline Massachusetts & 10,382 & 10,435 & 9,923 & 9,282 & 9,366 & .5 & -4.9 & -6.4 & .9 \\
\hline Michigan & 11,722 & 11,539 & 11,160 & 10,322 & 10,490 & -1.6 & -3.3 & -7.5 & 1.6 \\
\hline Minnesota & 10,205 & 10,505 & 10,258 & 9,710 & 10,150 & 2.9 & -2.4 & -5.3 & 4.5 \\
\hline Mississippi & 10,446 & 10,505 & 10,480 & 10,375 & 10,431 & .6 & -.2 & -1.0 & .5 \\
\hline Missouri & 10,840 & 11,171 & 11,203 & 10,574 & 10,702 & 3.0 & .3 & -5.6 & 1.2 \\
\hline Montana & 9,945 & 9,977 & 10,032 & 9,948 & 9,507 & .3 & .6 & -.8 & -4.4 \\
\hline Nebraska & 9,590 & 9,990 & 10,168 & 9,557 & 9,518 & 4.2 & 1.8 & -6.0 & -.4 \\
\hline Nevada & 9,720 & 9,746 & 9,797 & 9,198 & 9,570 & .3 & .5 & -6.1 & 4.0 \\
\hline New Hampshire & 11,888 & 11,638 & 11,328 & 10,357 & 10,900 & -2.1 & -2.7 & -8.6 & 5.2 \\
\hline New Jersey & 11,583 & 12,202 & 11,824 & 11,334 & 11,661 & 5.3 & -3.1 & -4.1 & 2.9 \\
\hline New Mexico & 12,123 & 12,736 & 13,048 & 12,362 & 12,003 & 5.0 & 2.4 & -5.2 & -2.9 \\
\hline New York & 9,136 & 9,292 & 9,234 & 8,751 & 8,579 & 1.7 & -.6 & -5.2 & -2.0 \\
\hline North Carolina & 10,454 & 10,569 & 10,390 & 9,805 & 9,866 & 1.1 & -1.7 & -5.6 & .6 \\
\hline North Dakota & 8,906 & 8,878 & 8,768 & 8,301 & 8,173 & -.3 & -1.2 & -5.3 & -1.5 \\
\hline Ohio & 10,103 & 9,900 & 9,809 & 9,057 & 8,934 & -2.0 & -.9 & -7.7 & -1.4 \\
\hline Ok1 ahoma & 10,409 & 10,642 & 10,923 & 10,533 & 10,756 & 2.2 & 2.6 & -3.6 & 2.1 \\
\hline Oregon & 10,044 & 10,182 & 9,940 & 9,636 & 9,792 & 1.4 & -2.4 & -3.0 & 1.6 \\
\hline Pennsylvania & 10,210 & 10,698 & 10,142 & 8,899 & 8,317 & 4.8 & -5.2 & -12.2 & -6.5 \\
\hline Rhode Island & 9,897 & 10,095 & 9,724 & 9,763 & 10,060 & 2.0 & -3.7 & .4 & 3.0 \\
\hline South Carolina & 12,845 & 13,004 & 12,759 & 11,976 & 11,625 & 1.2 & -1.9 & -6.1 & -2.9 \\
\hline South Dakota & 10,908 & 10,890 & 10,575 & 10,047 & 9,714 & -.2 & -2.9 & -5.0 & -3.3 \\
\hline Tennessee & 12,748 & 13,006 & 13,180 & 12,242 & 12,080 & 2.0 & 1.3 & -7.1 & -1.3 \\
\hline Texas & 10,293 & 10,468 & 10,352 & 9,771 & 10,074 & 1.7 & -1.1 & -5.6 & 3.1 \\
\hline Utah & 9,200 & 9,658 & 9,357 & 9,210 & 9,399 & 5.0 & -3.1 & -1.6 & 2.0 \\
\hline Vermont & 12,726 & 12,435 & 12,158 & 10,986 & 11,543 & -2.3 & -2.2 & -9.6 & 5.1 \\
\hline Virginia & 12,656 & 12,570 & 11,591 & 10,604 & 10,656 & -.7 & -7.8 & -8.5 & .5 \\
\hline Washington & 10,106 & 9,974 & 9,895 & 9,239 & 9,459 & -1.3 & -.8 & -6.6 & 2.4 \\
\hline West Virginia & 10,573 & 11,227 & 11,200 & 10,817 & 10,942 & 6.2 & -.2 & -3.4 & 1.2 \\
\hline Wisconsin & 11,594 & 11,682 & 11,609 & 10,850 & 11,033 & .8 & -.6 & -6.5 & 1.7 \\
\hline Wyoming & 12,427 & 12,313 & 11,769 & 11,252 & 10,932 & -.9 & -4.4 & -4.4 & -2.8 \\
\hline District of Columbia & 11,095 & 11,349 & 11,500 & 11,261 & 12,064 & 2.3 & 1.3 & -2.1 & 7.1 \\
\hline Total U.S. & 10,475 & 10,646 & 10,474 & 9,873 & 10,004 & 1.6 & -1.6 & -5.7 & 1.3 \\
\hline
\end{tabular}

Source: U.S. Department of Transportation, Federal Highway Administration, Highway Statistics, Washington, D.C., 1971-75, Table MV-1 and Table VM-2. 
Table 7. 1971-75 Annual Vehicle-Miles per Household and Percent Change by State

\begin{tabular}{|c|c|c|c|c|c|c|c|c|c|}
\hline \multirow[b]{2}{*}{ State } & \multicolumn{5}{|c|}{ Annual miles per household } & \multicolumn{4}{|c|}{ Percent change } \\
\hline & 1971 & 1972 & 1973 & 1974 & 1975 & $1971-2$ & $1972-3$ & $1973-4$ & $1974-5$ \\
\hline Alabama & 19,687 & 20,373 & 21,556 & 21,003 & 21,375 & 3.4 & 5.8 & -2.6 & 1.8 \\
\hline Alaska & 17,488 & 17,168 & 18,089 & 22,287 & 26,392 & -1.8 & 5.3 & 23.2 & 18.4 \\
\hline Arizona & 22,169 & 22,566 & 24,463 & 22,345 & 21,894 & 1.8 & 8.4 & -8.6 & -2.0 \\
\hline Arkansas & 18,687 & 18,809 & 19,726 & 19,362 & 19,446 & .6 & 4.9 & -1.8 & .4 \\
\hline California & 17,168 & 17,629 & 18,057 & 17,176 & 17,358 & 2.7 & 2.4 & -4.8 & 1.1 \\
\hline Colorado & 19,106 & 19,808 & 20,012 & 19,142 & 19,321 & 3.7 & 1.0 & -4.3 & .9 \\
\hline Connecticut & 17,770 & 17,904 & 18,514 & 17,844 & 17,807 & .8 & 3.4 & -3.6 & -.2 \\
\hline Delaware & 18,509 & 18,923 & 19,672 & 18,784 & 19,385 & 2.2 & 4.0 & -4.5 & 3.2 \\
\hline Florida & 18,974 & 20,077 & 21,622 & 19,939 & 20,308 & 5.8 & 7.7 & -7.8 & 1.8 \\
\hline Georgia & 21,962 & 22,290 & 23,511 & 22,776 & 24,982 & 1.5 & 5.5 & -3.1 & 9.7 \\
\hline Hawai i & 16,809 & 16,198 & 17,342 & 16,198 & 16,854 & -3.6 & 7.1 & -6.6 & 4.0 \\
\hline Idaho & 21,204 & 21,427 & 21,996 & 22,012 & 22,079 & 1.0 & 2.6 & .1 & .3 \\
\hline Illinois & 15,955 & 16,084 & 16,541 & 15,934 & 16,273 & .8 & 2.8 & -3.7 & 2.1 \\
\hline Indiana & 20,596 & 21,374 & 22,542 & 21,236 & 21,287 & 3.8 & 5.5 & -5.8 & .2 \\
\hline Iowa & 19,153 & 19,500 & 20,349 & 19,630 & 20,075 & 1.8 & 4.4 & -3.5 & 2.3 \\
\hline Kansas & 18,457 & 18,963 & 19,977 & 19,416 & 19,601 & 2.7 & 5.3 & -2.8 & 1.0 \\
\hline Kentucky & 20,965 & 21,556 & 22,971 & 22,006 & 22,403 & 2.8 & 6.6 & -4.2 & 1.8 \\
\hline Louisiana & 16,028 & 16,283 & 16,932 & 16,835 & 17,182 & 1.6 & 4.0 & -.6 & 2.1 \\
\hline Maine & 20,526 & 20,676 & 20,874 & 19,802 & 20,046 & .7 & 1.0 & -5.1 & 1.2 \\
\hline Maryland & 18,090 & 18,446 & 19,924 & 18,297 & 19,023 & 2.0 & 8,0 & -8.2 & 4.0 \\
\hline Massachusetts & 15,384 & 15,627 & 15,589 & 14,807 & 15,031 & 1.6 & -.2 & -5.0 & 1.5 \\
\hline Michigan & 20,228 & 20,358 & 20,555 & 19,197 & 19,740 & .6 & 1.0 & -6.6 & 2.8 \\
\hline Minnesota & 19,503 & 19,966 & 20,225 & 19,315 & 19,833 & 2.4 & 1.3 & -4.5 & 2.7 \\
\hline Mississippi & 18,526 & 19,045 & 19,733 & 19,628 & 19,969 & 2.8 & 3.6 & -.5 & 1.7 \\
\hline Missouri & 17,280 & 18,133 & 19,016 & 18,138 & 18,602 & 4.9 & 4.9 & -4.6 & 2.6 \\
\hline Montana & 22,325 & 22,576 & 23,606 & 23,575 & 22,621 & 1.1 & 4.6 & -.1 & -4.0 \\
\hline Nebraska & 20,026 & 20,967 & 21,783 & 20,958 & 21,233 & 4.7 & 3.9 & -3.8 & 1.3 \\
\hline Nevada & 20,822 & 20,686 & 22,771 & 20,975 & 21,239 & -.6 & 10.1 & -7.9 & 1.2 \\
\hline New Hampshire & 20,618 & 20,803 & 20,610 & 19,456 & 19,887 & .9 & -.9 & -5.6 & 2.2 \\
\hline New Jersey & 18,850 & 19,824 & 20,367 & 19,800 & 20,118 & 5.2 & 2.7 & -2.8 & 1.6 \\
\hline New Mexico & 25,689 & 26,427 & 28,432 & 27,356 & 27,712 & 2.9 & 7.6 & -3.8 & 1.3 \\
\hline New York & 10,395 & 10,504 & 10,933 & 10,467 & 10,316 & 1.0 & 4.1 & -4.2 & -1.4 \\
\hline North Carolina & 19,853 & 20,612 & 21,578 & 20,552 & 20,884 & 3.8 & 4.7 & -4.8 & 1.6 \\
\hline North Dakota & 20,816 & 20,788 & 21,827 & 21,855 & 22,287 & -.1 & 5.0 & .1 & 2.0 \\
\hline Ohio & 18,068 & 18,306 & 18,765 & 17,927 & 18,046 & 1.3 & 2.5 & -4.5 & .7 \\
\hline Oklahoma & 20,988 & 21,735 & 23,404 & 22,817 & 23,696 & 3.6 & 7.7 & -2.5 & 3.8 \\
\hline Oregon & 19,618 & 19,681 & 20,649 & 19,029 & 19,460 & .3 & 4.9 & -7.8 & 2.3 \\
\hline Pennsylvania & 16,135 & 17,233 & 17,322 & 16,182 & 16,006 & 6.8 & .5 & -6.6 & -1.1 \\
\hline Rhode Island & 16,600 & 17,187 & 17,542 & 18,058 & 18,436 & 3.5 & 2.1 & 2.9 & 2.1 \\
\hline South Carolina & 22,906 & 23,834 & 25,034 & 23,796 & 23,874 & 4.0 & 5.0 & -4.9 & .3 \\
\hline South Dakota & 23,053 & 23,217 & 23,796 & 23,150 & 22,793 & .7 & 2.5 & -2.7 & -1.5 \\
\hline Tennessee & 21,360 & 22,328 & 24,501 & 23,136 & 23,808 & 4.5 & 9.7 & -5.6 & 2.9 \\
\hline Texas & 19,919 & 20,238 & 21,331 & 20,136 & 21,088 & 1.6 & 5.4 & -5.6 & 4.7 \\
\hline Utah & 20,546 & 20,558 & 21,585 & 21,367 & 22,184 & .1 & 5.0 & -1.0 & 3.8 \\
\hline Vermont & 21,791 & 22,434 & 22,863 & 20,812 & 21,802 & 3.0 & 1.9 & -9.0 & 4.8 \\
\hline Virginia & 21,037 & 21,681 & 22,835 & 21,574 & 21,759 & 3.1 & 5.3 & -5.5 & .8 \\
\hline Washington & 19,192 & 19,081 & 19,997 & 18,558 & 19,249 & -.6 & 4.8 & -7.2 & 3.7 \\
\hline West Virginia & 15,365 & 16,624 & 17,323 & 17,005 & 17,500 & 8.2 & 4.2 & -1.8 & 2.9 \\
\hline Wisconsin & 18,628 & 19,050 & 19,958 & 19,024 & 19,094 & 2.3 & 4.8 & -4.7 & .4 \\
\hline Wyoming & 28,941 & 29,043 & 29,819 & 28,529 & 29,222 & .4 & 2.7 & -4.3 & 2.4 \\
\hline District of Columbia & 10,729 & 10,709 & 11,044 & 10,675 & 11,007 & -.2 & 3.1 & -3.3 & 3.1 \\
\hline Total U.S. & 18,127 & 18,838 & 19,148 & 18,259 & 18,593 & 3.9 & 1.6 & -4.6 & 1.8 \\
\hline
\end{tabular}

Source: U.S. Department of Transportation, Federal Highway Administration, Highway Statistics, Washington, D.C., 1971-75, Table MV-1 and Table VM-2. 
are presently considering changes in their VMT estimating procedures to reflect greater statewide interest in transportation energy conservation.

In the next step of the study, all fifty states and the District of Columbia were surveyed for the method each uses in preparing annual estimates of VMT. TERA surveyed state DOT officials by telephone and then summarized individual state practices in estimating VMT. These summaries were later mailed to the respective states by ORNL (Appendix) and comments were requested. Corrections and clarifications received were then incorporated in the final summaries.

Basically, there are two methods by which states estimate VMT - traffic count and fuel use. The methods are used either individually or together. However, state VMT estimates, whether based upon traffic counts or fuel use, do not separate out-of-state vehicles from in-state vehicles. Therefore, state estimates do not accurately reflect the driver behavior patterns of residents of a particular state. For example, in a state like Florida where there are many out-of-state vehicles, the VMT of these tourists is included in the VMT reported by the state.

\subsection{Traffic count method}

The most widely used method of estimating VMT is by traffic count. The procedures used in this method differ only slightly from state to state. In all cases where traffic count is used, road systems are put into FHWA categories (interstate, federal-aid and local) and divided into section lengths. These sections are then monitored either manually or by automatic traffic recorders for the volume of traffic. Traffic counts are either done on selected sample lengths of road sections or are based on a total coverage count of the whole system. These counts usually occur over a two- to nine-year cycle depending upon the mileage in the state and the number of counters used. The duration of the traffic count also varies greatly - from $12 \mathrm{~h} / \mathrm{y}$ per section length, when total coverage is being attempted, to $24 \mathrm{~h} / \mathrm{d}$ for each day of the year per section length (permanent counting station) when sample sections are continuously monitored. In some states, both total coverage over 
multiple-year cycles and permanent counting over selected sections are done. The result of each is adjusted to reflect seasonal variations in traffic volume. The result of traffic counting is an estimated average daily traffic (ADT) by road category. The ADT is then expanded to an average annual traffic estimate; that is, the traffic volume over one system for one year. This figure is then multiplied by the mileage in that system to obtain a VMT estimate for that particular system. In states where traffic counting is the only method used, the total VMT for the state is the sum of VMT estimates for all road categories.

\subsection{Fuel consumption method}

The fuel use method of estimating VMT also varies among states. However, compared to the traffic count method, there are fewer variables used to calculate the VMT. In most cases, the VMT estimate is the product of the gallons of motor fuel used by vehicles in one year and an assumed average miles-per-gallon estimate for the state. The source for motor fuel use data is usually fuel tax receipts. The average miles-per-gallon figure is either suggested by FHWA, and adjusted by the state, or past state studies are projected for the current year.

In some cases, a more complicated version of the above method is used to estimate the motor fuel used in the state. For example, in Oregon, there is a weight/mile tax for trucks of various classifications which requires the weighing stations to record odometer readings for each truck. In addition, the state also surveys large intrastate trucking firms for average annual VMT for trucks. The combination of the two estimates is then used to estimate total truck VMT. For passenger car VMT, Oregon uses an average miles-per-gallon value established in a 1967 fuel use study and projected yearly in proportion to changes in the nationa1 average.

\subsection{Individual state practices to estimate VMT}

The methods used to estimate VMT every year as reported to the Federal Highway Administration vary by individual state (Table 8). 
Table 8. Comparative Summary of State Practices to Estimate VMT

\begin{tabular}{|c|c|c|c|c|c|c|c|c|c|c|c|}
\hline \multirow[b]{3}{*}{ State } & \multirow{2}{*}{\multicolumn{4}{|c|}{ Traffic count method }} & \multicolumn{7}{|c|}{ Fuel consumption method } \\
\hline & & & & & \multicolumn{4}{|c|}{ Fuel consumption estimate } & \multicolumn{3}{|c|}{ Miles per gallon estimate } \\
\hline & $\begin{array}{c}\text { Permanent } \\
\text { station }\end{array}$ & $\begin{array}{l}\text { Seasonal/ } \\
\text { sample }\end{array}$ & $\begin{array}{l}\text { Complete } \\
\text { system } \\
\text { coverage }\end{array}$ & $\begin{array}{l}\text { Manual/ } \\
\text { automatic }\end{array}$ & $\begin{array}{c}\text { Tax } \\
\text { records }\end{array}$ & $\begin{array}{l}\text { Ratio to } \\
\text { national }\end{array}$ & $\begin{array}{l}\text { Whole- } \\
\text { sale } \\
\text { figures }\end{array}$ & Other & $\begin{array}{l}\text { Empirical } \\
\text { study }\end{array}$ & $\begin{array}{l}\text { FHWA } \\
\text { guideline }\end{array}$ & Other \\
\hline Alabama & $\mathrm{x}$ & $\mathrm{X}$ & & A & & & & & & & \\
\hline Alaska & $\mathrm{x}$ & $\mathrm{x}$ & $x$ & & $\mathrm{X}$ & & & & $\mathrm{x}$ & & \\
\hline Arizona & & $\mathrm{X}$ & & A & & & & $\mathrm{X}$ & & $\mathrm{X}$ & \\
\hline Arkansas & $\mathrm{x}$ & $\mathrm{x}$ & $\mathrm{x}$ & A & & & & & & & \\
\hline California & $\mathrm{X}$ & $\mathrm{x}$ & & A & $x$ & & & & & & $\mathrm{X}$ \\
\hline Colorado & $\mathrm{x}$ & $\mathrm{X}$ & & A & & & & & & & \\
\hline Connecticut & & & $x$ & A & & & & $\mathrm{x}$ & & & \\
\hline Delaware & & $\mathrm{x}$ & & A & & & & & & & \\
\hline Florida & $\mathrm{X}$ & $\mathrm{x}$ & & A & & & & & & & \\
\hline Georgia & $\mathrm{X}$ & $\mathrm{x}$ & $\mathrm{x}$ & A & & & & & & & \\
\hline Hawaii & $\mathrm{x}$ & $\mathrm{X}$ & & A & $x$ & & & & $\mathrm{X}$ & & $\mathrm{x}$ \\
\hline Idaho & & $\mathrm{X}$ & & A & $\mathrm{X}$ & & & & & & \\
\hline Illinois & $\mathrm{x}$ & $\mathrm{X}$ & & A & $\mathrm{X}$ & & & & & $\mathrm{X}$ & \\
\hline Indiana & $\mathrm{X}$ & $\mathrm{x}$ & & A & $\mathrm{X}$ & & & & & $\mathrm{X}$ & \\
\hline Iowa & $\mathrm{x}$ & $x$ & $\mathrm{x}$ & A & & & & & & & \\
\hline Kansas & & $\mathrm{x}$ & $\mathrm{X}$ & A & & & & & & & \\
\hline Kentucky & $\mathrm{x}$ & $\mathrm{x}$ & & A & $\mathrm{X}$ & & & & $\mathrm{X}$ & & \\
\hline Louisiana & $\mathrm{X}$ & $\mathrm{x}$ & $\mathrm{x}$ & A & & & & & & & \\
\hline Maine & & $\mathrm{x}$ & $\mathrm{X}$ & A & $\mathrm{X}$ & & & & & $\mathrm{X}$ & \\
\hline Maryland & & $\mathrm{x}$ & $x$ & A & & & & & & & \\
\hline Massachusetts & $\mathrm{X}$ & $\mathrm{X}$ & & A & & & & & & & \\
\hline Michigan & & & & & $\mathrm{X}$ & & & & $\mathrm{X}$ & & \\
\hline Minnesota & $\mathrm{X}$ & $\mathrm{X}$ & $\mathrm{x}$ & A & & & & & & & \\
\hline Mississippi & & $\mathrm{x}$ & $x$ & A & & & & $\mathrm{X}$ & & & $\mathrm{X}$ \\
\hline Missouri & $\mathrm{x}$ & $x$ & $\mathrm{x}$ & M/A & & & & $\mathrm{x}$ & & & $\mathrm{x}$ \\
\hline Montana & $x$ & $x$ & & A & $\mathrm{x}$ & & & & $\mathrm{X}$ & & \\
\hline Nebraska & $\mathrm{x}$ & $x$ & $x$ & M/A & & & & $\mathrm{x}$ & & & $\mathrm{X}$ \\
\hline Nevada & $\mathrm{x}$ & $\mathrm{x}$ & & A & & & & & & & \\
\hline New Hampshire & $\mathrm{x}$ & $\mathrm{x}$ & & A & $\mathrm{x}$ & & & & & & $\mathrm{X}$ \\
\hline New Jersey & $\mathrm{x}$ & $\mathrm{x}$ & $x$ & $\mathrm{M} / \mathrm{A}$ & $\mathrm{x}$ & & & & $\mathrm{X}$ & & \\
\hline New Mexico & $\mathrm{x}$ & $\mathrm{X}$ & $\mathrm{x}$ & A & & & & $x^{e}$ & & & \\
\hline North Carolina & & $x$ & & $\mathrm{~A}$ & & & & $\hat{x}$ & & & \\
\hline North Dakota & $\mathrm{X}$ & $\mathrm{x}$ & & $\mathrm{M} / \mathrm{A}$ & & & & & & & \\
\hline Ohio & $\mathrm{x}$ & $\mathrm{X}$ & & A & $\mathrm{X}$ & & & & $\mathrm{X}$ & & \\
\hline Oklahoma & $\mathrm{x}$ & $x$ & & A & $\mathrm{x}$ & & & & $\mathrm{x}$ & & \\
\hline Oregon & & $\mathrm{x}$ & $\mathrm{x}$ & A & & & & $x^{f}$ & $\mathrm{X}$ & & \\
\hline
\end{tabular}


Table 8 (continued)

\begin{tabular}{|c|c|c|c|c|c|c|c|c|c|c|c|}
\hline \multirow[b]{3}{*}{ State } & \multirow{2}{*}{\multicolumn{4}{|c|}{ Traffic count method }} & \multicolumn{7}{|c|}{ Fuel consumption method } \\
\hline & & & & & \multicolumn{4}{|c|}{ Fuel consumption estimate } & \multicolumn{3}{|c|}{ Miles per gallon estimate } \\
\hline & $\begin{array}{l}\text { Permanent } \\
\text { station }\end{array}$ & $\begin{array}{l}\text { Seasonal/ } \\
\text { sample } b\end{array}$ & $\begin{array}{l}\text { Complete } \\
\text { system } \\
\text { coverage }\end{array}$ & $\begin{array}{l}\text { Manual/ } d \\
\text { automatic }\end{array}$ & $\begin{array}{l}\text { Tax } \\
\text { records }\end{array}$ & $\begin{array}{l}\text { Ratio to } \\
\text { national }\end{array}$ & $\begin{array}{l}\text { Whole- } \\
\text { sale } \\
\text { figures }\end{array}$ & Other & $\begin{array}{l}\text { Empirical } \\
\text { study }\end{array}$ & $\begin{array}{l}\text { FHWA } \\
\text { guideline }\end{array}$ & Other \\
\hline Pennsylvania & & $\mathrm{X}$ & $\mathrm{x}$ & A & & $x$ & & & $x$ & & \\
\hline Rhode Island & & $x$ & & $\mathrm{M} / \mathrm{A}$ & & & & & & & \\
\hline South Carolina & & $\mathrm{X}$ & & A & $\mathrm{X}$ & & & & $\mathrm{X}$ & & \\
\hline South Dakota & $X$ & & $\mathrm{X}$ & A & & & & & & & \\
\hline Tennessee & $\mathrm{x}$ & & & A & $\mathrm{X}$ & & & & $\mathrm{X}$ & & \\
\hline Texas & $\mathrm{X}$ & $\mathrm{X}$ & & A & & & & & & & \\
\hline Utah & $x$ & $\mathrm{x}$ & $\mathrm{x}$ & A & & & & & & & \\
\hline Vermont & & $\mathrm{x}$ & $\mathrm{x}$ & A & & & & & & & \\
\hline Virginia & & $\mathrm{X}$ & $\mathrm{X}$ & A & & & & $\mathrm{X}$ & & & $\mathrm{X}$ \\
\hline Washington & $\mathrm{x}$ & $\mathrm{X}$ & & A & & & & & & & \\
\hline West Virginia & & $\mathrm{x}$ & $\mathrm{X}$ & A & & & & & & & \\
\hline Wisconsin & & $\mathrm{x}$ & & A & $\mathrm{x}$ & & & & $\mathrm{X}$ & & \\
\hline Wyoming & $\mathrm{x}$ & $\mathrm{X}$ & & A & & & & & & & \\
\hline District of Columbia & $x$ & $X$ & & M/A & & & & & & & \\
\hline
\end{tabular}

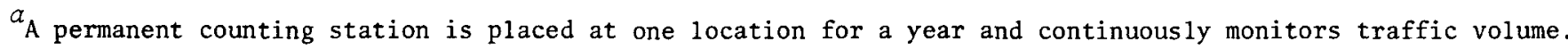

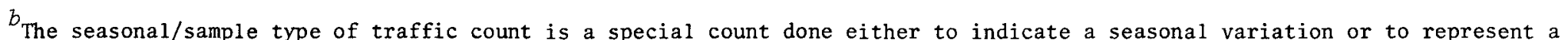
percentage of the state's mileage which can be expanded to represent the total.

${ }^{c}$ Complete system coverage traffic counts may involve only one road classification or all in a state. In either case, the $\operatorname{system}(s)$ is broken into section lengths, each of which is monitored and for which an ADT is calculated. Complete coverage means that every mile of the system(s) is included in the count and the VMT is actual rather than expanded from a sample.

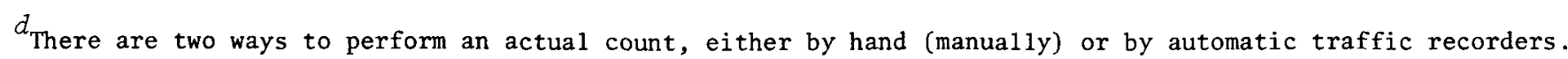

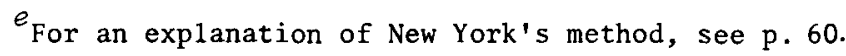

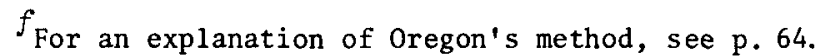

Source: TERA, Inc., Existing Data on Vehicle-Miles Traveled in the United States, July 1977, Fig. 6, p. 52. 
Alabama

In Alabama, for the federal aid, interstate, primary and state highway systems, VMT is based upon traffic count. On the interstate highways there is one count between each interchange. On those highways where there are many exits and entrances, the highway is divided into sections of varying length on which an average daily traffic (ADT) is determined. Traffic counts are done at least once a year for $72 \mathrm{~h}$ for each traffic count being taken and then adjusted against the ADT generated from permanent traffic counters. On secondary and local roads, the average ADT is estimated from a fivecounty sample.

In all cases, once an ADT for each road category is obtained, VMT is calculated by multiplying the ADT by the mileage in each category. Total state VMT is the sum of VMTs for each road category.

Alaska

Alaska uses both traffic count and fuel use to estimate VMT. Total VMT is estimated by multiplying the number of gallons of motor fuel used (estimated from tax receipts) by an mpg value obtained from a survey in the early 1970s. To measure VMT by road category, Alaska does some continuous counts, seasonal counts, and a complete coverage count on a cycle from two to five years. Counts are done only on the major highway systems. For the local and municipal roads, VMT is estimated by apportioning the remainder of the VMT after VMT on the major systems is subtracted from the total.

Arizona

Arizona's method of estimating annual VMT is based upon a combination of traffic count and fuel data. For primary and secondary road systems, 1600 traffic counters are used on an annual basis to estimate ADTs. For the remaining road systems, VMT for primary and secondary systems is subtracted from the total VMT based upon fuel used and an average mpg value. The remaining VMT by road category is estimated. In 1972, the state changed its procedure for estimating fuel use from sales tax receipts to monitoring the amount of fuel brought into the state, 
including fuel in storage. The miles-per-gallon value used to estimate total VMT has been the FHWA estimates. However, the state is considering an attempt to calculate its own miles-per-gallon estimate, which is expected to be higher than the currently used figure.

Arkansas

Arkansas uses traffic count to estimate annual VMT. Total coverage counts by counties are done for eight to ten counties per year, and a complete coverage of the state is made on a seven- to nine-year cycle. Roads in each county are grouped by category to generate an ADT per road type per county, which is then averaged out against the other counties counted in one year. In addition, approximately 4500 counting stations monitor traffic on a statewide basis on the various road systems, and these are used as a sample to further adjust the VMT as estimated from the coverage count of county roads systems.

All traffic counting is done by approximately 80 stationary automatic recorders, which count continuously, and other machine counters which are moved from place to place.

\section{Ca1ifornia}

California estimates VMT from a combination of fuel use and traffic count. Total VMT for the state is calculated from motor fuel used (estimated from tax receipts) and an average mpg value for the state which is adjusted against the national average. VMT by road categories is generated from ADTs which are established by a sample of traffic counts throughout the state. Traffic counts on most systems are not very extensive. However, large urban areas are well covered. The two total estimates are then compared and adjusted to reflect trends in other indicators such as the number of vehicles and growth in total motor fuel use.

\section{Colorado}

Colorado uses traffic count to estimate VMT. Permanent counters on sections of different state highway systems are used as a sample to generate ADTs and a total VMT by type of highway system. These are 
used primarily as trend indicators. Major state highway interchanges are counted every two years by approximately 1500-2000 additional counters. Data from the counts are also used to generate comparative ADTs which are then compared with ADTs from permanent counters and an average computed.

VMT for local and county roads off the state highway system is estimated on the basis of counts taken in 1970 and 1971 and updated according to trends in the immediate area. ADTs by road classification are the basis of computing VMT by road system, and the total VMT for the state is the sum of VMT for each road system.

Connecticut

Connecticut uses traffic count and fuel use to estimate annual VMT. Over the 4000 miles of the state highway system, a total coverage count is made every two years. On unlimited access highways, traffic counters are placed at major traffic interchanges so that the total traffic count includes vehicles entering and leaving the particular section of highway that is being counted. VMT is calculated by multiplying the number of vehicles and number of miles per section. To estimate the annual total VMT in those years where the total coverage count has not been completed, the previous year's total VMT is compared against the halfway count and adjusted to reflect the appropriate growth.

VMT for state highways is then subtracted from the total control VMT estimated by multiplying the gallons of motor fuel sold by an assumed average miles-per-gallon value. The remaining VMT is then allocated among the lower road classifications such as local and rural.

$\underline{\text { Delaware }}$

Delaware uses traffic count to estimate total VMT. Of the 4500 state-maintained highways, 3900 are counted every one to two years by varying lengths of sections. For each section length, an average-dailytraffic (ADT) is calculated for the time counted and then projected to give an annual ADT (AADT) which is multiplied by the length of the section to obtain annual VMT by section length. Annual VMT for each section is then added up for all the sections for which counts are taken. Counts are taken for one to two weeks every season so that total figures reflect 
seasonal variance to some degree. For the remaining 600 miles of statemaintained highways, VMT is estimated by assigning an average AADT assumed to be representative of the whole system.

For the 700 miles of local and municipal roads, no counting is done. Again, these are broken into sections which are assigned different AADTs to calculate total VMT. Assignment of an AADT to local and municipal roads is subjective.

District of Columbia

The VMT for the District of Columbia is estimated from traffic counts. All major, minor, and interstate routes in the District are monitored and assigned ADT values from which total mileage is projected. Traffic counted annually on the major, minor, and interstate routes includes most business routes. On the other hand, residential areas are seldom counted. The District uses 77 permanent counters and manual and portable machine counts to generate ADT figures. As in other states, ADT values are multiplied by system mileage and 365 days to calculate annual VMT.

Florida

Florida uses traffic count to estimate annual VMT. The statemaintained highways are estimated to carry two-thirds of total state VMT because most of these highways are arteries. On this system, approximately 80 permanent counters on representative sections of highway measure traffic daily; from this an ADT is estimated. A1so, 5000 seasonal counts (one day four times a year) are made on highways and 5000 urban roads. ADTs are then used to compute VMT by road type. Counting is done annually. Counting stations are placed at major intersections where access is unlimited on both sides, and the counts are averaged.

On remaining off-system roads, increased VMT is estimated by using an AADT which is checked for reasonableness against gas use figures and the number of new cars in fleet mix. This increase is applied to a baseyear figure to estimate VMT for off-system roads. 
$\underline{\text { Georgia }}$

The defined coverage counting program in Georgia uses some 22,000 stations operating for $24 \mathrm{~h}$ annually. The program covers about 31,400 miles of road including a11 state and federal-aid highways. Each coverage count is adjusted (using factors obtained from continuous count and seasonal control stations) to an estimate of ADT. This estimate of ADT is multiplied by the mileage of the road segment that it represents to produce daily vehicle miles of travel for that one link. U1timately all similar system links are added together to produce VMT for the entire state for the various administrative systems. This technique provides estimates of VMT which are mostly based on counts of the state and federal-aid highways.

The administrative systems that are not accounted for by this procedure are the local county road and city street systems of the state. To obtain VMT estimates on these systems, a 5\% random sample of a11 county roads and city streets in each county are selected and counted annually. Locations counted through this $5 \%$ sample are averaged to find an ADT that represents city streets and county roads in each of the counties of the state.

Hawaii

Hawaii to estimates VMT from both fuel use and traffic count. Total VMT for the state is estimated by multiplying gallons of motor fuel used by a standard 14-mpg value. Data on fuel use by motor vehicles is obtained from fuel tax receipts. To measure total VMT by road categories, sample seasonal traffic counts along with a continuous count program are used on the state and federal road systems to arrive at ADT values for each category. For county and city roads not counted, the VMT is estimated by subtracting VMT on state and federal road systems from the base total and apportioned out on a judgmental basis. Thus, the main data used in estimating VMT is fuel use data. Traffic counts on the major highway systems are used to establish the total VMT by system. 
$\underline{\text { Idaho }}$

Idaho calculates total state VMT from estimated fuel use. Total VMT is calculated from fuel tax receipts and an mpg value. The mpg estimate currently used represents closely the national average since there seems to be a high correlation according to the state. To find VMT by road class, traffic counts on all state-administered roads are used to generate ADTs.

For the remaining systems not counted, VMT for the state-administered system is subtracted from the total VMT and the remainder is apportioned to the remaining systems on a judgmental basis.

\section{Illinois}

I11inois' estimates VMT from estimated motor fuel use (based on tax receipts) and the national average mpg per vehicle. A further division of VMT by road is based upon traffic counts with approximately 65 permanent counters and many seasonal counts seven days per month for nine months each to generate ADT values for the county, state, and federal road systems. No counts are taken on municipal and local roads. The VMT for local and municipal roads is estimated by subtracting the VMT on the county, state, and federal road systems from the base total and allocating the remaining VMT on the basis of traffic counts taken on these road systems in the past.

Indiana

Indiana estimates total VMT using the FHWA 12.5 -mpg value and motor fuel use data. To measure the total VMT by the various road systems, Indiana uses traffic count with 32 permanent and 300 portable counters. To cover the state-administered and federal-aid highway systems takes a cycle of three to four years. Annually, sample locations are chosen to generate ADTs by road system. VMTs for the state and federal-aid road systems are calculated by multiplying assigned annual ADTs by the number of miles of road in each road system. VMT estimates supplied by some cities are used to estimate an ADT for city streets which, in turn, is used to calculate VMT. Total VMT by traffic count 
is then compared against the total control VMT generated from fuel use data, and VMT for the state is adjusted using the two estimates. Generally, if VMT from the traffic method differs greatly from the control figure, the control figure is reported as the final VMT estimate for the year. Iowa

Iowa's VMT estimate is based upon traffic count, but these data are also evaluated against vehicle registration and motor fuel use. VMT figures are also combined with population estimates for VMT per capita, but annual population estimates are not developed, and a ratio of two estimates could produce an inconsistent result from any given year. The road system is divided into four categories with each treated separately. For the state highway system, total coverage is over a two-year cycle by traffic counts at locations every six miles. Major county roads are covered over a four-year cycle at approximately four-mile intervals with statistically selected minor roads covered over an eight-year cycle. City street traffic is statistically sampled annually. Each of the above counts generates an annual ADT which is multiplied by the mileage in a road system and 365 days to estimate total VMT for the state. In addition, data from 56 permanent traffic counters on state highways are used to adjust ADT values. The permanent recorders generate information on an hourly and daily basis and indicate trends and seasonal variations.

Kansas

VMT statistics for Kansas are based upon traffic count. On state highways and their connecting links, 24-h machine counts are collected annually on interstate and other principal rural arteries. The connecting links of these routes are counted at the same time. A two-year cycle is adhered to on the remaining rural state highways and their connecting links with counts being collected on approximately one-half of those routes annually. Twenty-four-hour machine counts are done on county federal-aid secondary highways and their connecting links in two of the six highway districts each year so as to be on a three-year cycle. Complete 24-h machine coverage counts are collected on the county rural nonfederal-aid roads and city streets classified 
as collectors in nonurban areas on a continuous three-year cycle during the first three years of an overall six-year cycle. A systematic $5 \%$ sample of 24-h machine counts is collected on the county nonfederal-aid roads classified as local on a continuous three-year cycle during the second three years of the six-year cycle mentioned above. In urban areas, complete machine counts are made on all streets classified as collectors and above, other than state highway connecting links, on a continuous three-year cycle and on a sample of the streets classified as local on a continuous six-year cycle. In the nonurban areas, 24-h machine counts are collected on a continuous six-year cycle at systematically placed locations on streets classified as locals that are not connecting links of routes on the federal-aid system in the sample cities. In all cases, ADT values are multiplied by the road mileage and 365 (366 for leap years) to obtain annual VMT.

Kentucky

Kentucky estimates VMT with a combination of traffic count and fuel use data. To estimate the travel on the several highway systems within Kentucky, total VMT is estimated from fuel used in highway travel. These fuel data are furnished to the Division of Systems Planning annually by the Kentucky Department of Revenue and Bureau of Vehicle Regulation. The total estimated VMT is the product of total highway fuel used and average $\mathrm{mpg}$. The average mpg was determined from motor vehicle use and other related studies. The VMT on all federal-aid and state-maintained highways and streets is determined from a combination of permanent traffic recorder data and a statewide coverage count program. A statewide county coverage program is completed every five years for the federal-aid and state systems. A limited number of strategic locations are also counted biennially. Using factors derived from permanent traffic recorder locations, these counts are adjusted to AADT for an appropriate route segment and VMT estimated from these adjusted counts. This method measures all travel on the interstate, federal-aid primary, federal-aid urban, federal-aid secondary, and other state-maintained roads. The travel remaining after deducting the above VMT from the 
total is prorated among the remaining systems based on sample counts and motor vehicle use data for these systems. These sample counts on off-system rural roads and urban streets are part of the five-year count program.

Louisiana

In Louisiana, VMT is computed using traffic counts and section lengths of roadways. The Department has three traffic count programs which provide data for tabulating VMT. These are permanent recording stations, a routine count program, and a coverage (blanket) count program. There are 55 permanent recording stations (46 rural and 9 urban) to monitor hourly, daily, weekly, and monthly variations in traffic. The data obtained at these locations are also used in developing traffic trends and seasonal adjustment factors.

In the routine count program, taffic is counted annually at approximately 5000 locations on the 16,239 miles of state-maintained highway. These counts vary from 24-96 h. Each count location is identified with a section of roadway in an inventory file and is used to compute the annual VMT for that section of highway.

Annual VMT can be estimated for a section, route, parish, district, system, or the state. The coverage count program (blanket) is for roads and streets that are not on the state-maintained system.

Because of the size of this system, it generally takes from five to six years to obtain the data throughout the state. The count data are generally obtained after inventory crews have updated the road inventory data for a parish (county). Again, each roadway section is identified with a count location. The VMT is easily computed and for those years when counts are not made, the data can be estimated using an appropriate growth factor.

In the routine and coverage count programs, approximately 250 recorders of various types count the traffic; from this, a representative sample for state highways (urban and rural) and local rural roads is obtained. Counting on city streets is limited. 
Maine

Maine calculates its total annual VMT by mutilplying gallons of motor fuel sold by an estimated average mpg value for the state. The fuel data are obtained through fuel tax receipts and the average mpg value is suggested by the FHWA. To establish VMT by road categories, each system is counted separately. On the average, a $5-10 \%$ sample is used to estimate the ADT for each system annually. The state completes a total coverage count every five to seven years. Total VMT obtained by the two different methods is compared and adjusted.

Maryland

Maryland's estimate of VMT is based upon traffic counts on a11 road systems. On state highways and major routes which represent $25 \%$ of total VMT, traffic counts are done at each mile post on an annual basis continuously. On local and county roads, sample traffic counts on an annual basis are used to generate ADT values. ADT values are then converted to VMT by road categories which are added together to produce a total VMT for the state.

Massachusetts

The method for estimating VMT for Massachusetts is based upon traffic counts. Approximately 100 permanent and control counts and 1000 special counts sample the road network including most of higher road classifications. Section length counts are expanded to ADTs by road system and then multiplied by the mileage in each road system. Total VMT for the state is the sum of VMT for all road systems. In Massachusetts, counts are considered to be detailed and reliable and are currently being used to calibrate a transportation model for planning purposes.

Michigan

The Michigan Department of State Highways and Transportation (MDSHT) estimates VMT from fuel use and an average mpg figure. Fuel use is estimated from data from the Motor Fuel Tax Division of the Michigan Department of Treasury. The previously used average mpg figure is 
adjusted based on updated automobile fuel use figures obtained from the EPA. This new estimate is used with the total gallons used to estimate an overall statewide VMT. In MDSHT's computations, no allowance is made for fuel used by state-registered vehicles outside Michigan or out-of-state vehicles in Michigan. These two elements are assumed to balance each other out.

Michigan collects extensive traffic count data on the trunkline system. This data is used to obtain accurate estimates of ADT for each section of trunkline. These estimates are multiplied by the section length and accumulated to obtain trunkline VMT.

County and local VMT is the difference obtained by subtracting trunkline VMT from total statewide VMT (estimated from fuel use).

Michigan is waiting for the results of NCHRP Research Project 8-10, Improved Methods of Vehicle Counting and Determining Vehicle Miles of Travel. Possibly this research will provide improved VMT estimation methods.

Minnesota

Minnesota, in calculating total VMT for the state, counts its traffic three ways. Traffic counts are taken on all truck highways for 48-h periods with total coverage completed every other year. These counts are adjusted to an AADT. A second traffic counting system exists for secondary road systems by county. Total coverage for these road systems is completed over a six-year cycle. For other road systems such as local and municipal streets, sample counts are taken to estimate ADT. Concurrently, 100 permanent traffic recorders supply data which indicate trends and seasonal variations. These data are used to estimate VMT data and are used in factoring $48-\mathrm{h}$ counts to ADT.

\section{Mississippi}

Estimates of vehicle-miles of travel are computed on a statewide, county, and system basis from estimated average daily traffic and the mileage for each defined highway segment. The following narrative covers the general proceudres used for the coverage traffic counts and the mileage inventory. 
Coverage counts. Coverage traffic count collects a large sample of traffic volume data each year for all systems except local rural roads and city streets. All highway segments included in the coverage count process are sampled at least once every four years. However, random sampling techniques allows any segment to be selected in any given year. The sampling is statewide, so no county or urban area is covered extensively during any given year. The basis for scheduling counts is best explained by using the 1977 coverage counts as an example:

\begin{tabular}{r}
$\begin{array}{l}\text { Year of } \\
\text { coverage }\end{array}$ \\
\hline 1973 \\
1974 \\
1975 \\
1976
\end{tabular}

Highway segments scheduled

A11 segments

$5 \%$ statewide sample

$5 \%$ statewide sample

Statewide sample of 750 segments with ADT 500

A11 coverage counts are for 48-h usually between February and October. In 1976, approximately 3000 coverage counts were made. Approximately $10 \%$ of these counts were within urban areas. In addition, approximately $10 \%$ of the local rural system is eligible for selection in the coverage count process because some segments were classified as federal-aid secondary before a recent federal-aid realignment. Since these segments had a1ready been defined, they were retained as potential candidates for selection. Mississippi will continue to sample these segments.

Adjustments to coverage counts. All highway segments included in the coverage count are grouped according to patterns of monthly traffic volume variation. Mean factors adjusting average weekday traffic to ADT are determined for each group from data collected at continuous traffic counting stations. Coverage counts are adjusted to ADT by use of these group mean factors.

Growth factors are also applied to the latest ADTs on segments not included in the counting program for any given year. These growth factors are annually calculated from a random sample of traffic volume data collected at comparable locations for consecutive years. Thus, past data are reused until new sample counts are obtained. This procedure ensures that the most current traffic data for each segment are selected for the updating process. 
For both rural and urban local highway systems, ADTs are estimated for those segments not included in the coverage count. For the 1976 calculations $89 \%$ of the local rural mileage (and $97 \%$ of the local urban) was estimated rather than counted. Estimated ADTs are intentionally conservative to preclude excessive vehicle-mile estimates.

Mileage inventory

A11 state mileage is recorded by county as a part of the state's data base. Mileage on state-maintained segments is updated annually to include any construction completed in the past year. No estimates of mileage are made for other highway systems. Thus increases in local mileage will not be included until a county is inventoried. As with ADTs, this procedure results in conservative mileage figures and precludes the possibility of excessive vehicle-mile estimates.

\section{Vehicle-mile computation}

The ADTs and mileages are compiled each year for all highway segments on a11 highway systems. Vehicle-miles of travel is estimated or computed from the multiplication of ADT and mileage for each highway segment. These estimates are calculated on a system, county, and statewide basis. Current1y, no urban estimates are made.

Missouri

Missouri uses traffic count to estimate total VMT. On the 32,000 miles of the state-administered road system, total coverage counts of the various road categories are made every two years. These data, combined with classified counts and continuous counts from 88 permanent and 35 quarterly automatic traffic recorders, are used in developing the state's VMT statistics. Of the remaining 85,000 miles of county and city roads, random spot counts are used to estimate an ADT volume for these road systems. To check the VMT obtained by traffic count, Missouri also estimates VMT from motor fuel use data and an estimated mpg figure for the state. 
Montana

Montana combines two methods in estimating VMT data. A total control VMT is estimated from motor fuel used (estimated from tax receipts) and an average mpg value for the state. VMT by various road classifications is then estimated through the use of automatic traffic recorders. Montana has 43 permanent counters at fixed locations and 200-300 mobile recorders which are used to estimate traffic volumes on all primary, secondary, and urban road systems. Traffic counts are then averaged to calculate ADTs by road system which, in turn, are used to estimate annual VMT by road system. On those road systems which are not counted for traffic volume, the remaining VMT from the total is apportioned on a judgmental basis. Nebraska

Tota1 VMT for Nebraska is estimated from traffic count data from permanent count locations. This control total is checked against independent estimates from fuel used and $\mathrm{mpg}$. Adjustments are then made to reconcile the difference in the two estimates.

Vehicle-miles-traveled by road classification is based upon extensive traffic count data (from manual and portable machines) on all systems except unclassified local roads and city streets. The state highway system is completely covered every two years and all other systems every five years.

The VMT estimate for unclassified local road and city streets is the difference between the statewide total and the VMT on the counted systems. This difference is allocated among local road and city streets. Nevada

Nevada estimates annual VMT from traffic counts. For al1 state and federal-aid roads, 33 permanent and 2500 mobile counters give data for ADT values by road system. For off-system or local roads, the VMT estimates are updated base year figures, the most recent base year being 1971. Updates are based upon growth rates as reflected by spot counts at selected sections. 
New Hampshire

New Hampshire calculates VMT from a combination of traffic counts and fuel use and registration data. Based on the FHWA 1970 Needs Study, randomly selected sections of highways were inventoried to cover $100 \%$ of the interstate routes, $50 \%$ of principal arterial roads, $25 \%$ of minor arterial roads, $10 \%$ of collector roads, and $5 \%$ of local roads. These data were used to establish base year VMT values for 1970 .

Similar procedures were used to inventory these same sections in 1975 (NHIP study) and to verify previous (1971-74) ADT and VMT estimates and to establish a VMT base for 1975. Annual estimates to 1975 were based on the ADTs established in 1970 and expanded with factors generated from fuel consumption, and registration data.

Annual updates will continue from automatic traffic recorders, registration, and motor fuel tax data.

New Jersey

New Jersey estimates VMT by traffic count (both manually and by automatic traffic recorders) supplemented by fuel use data as an overall control. Some traffic counts are done on all highways with 43 permanent counting stations, approximately 1400 seasonal counting stations used for varying lengths of time, and $300024-\mathrm{h}$ coverage counts. Out of a 30,000-mile road system, approximately 6000 AADTs are generated from the traffic counts. Where there is insufficient traffic count coverage on the federal-aid systems in the current year, traffic counts from previous years are expanded to current year annual-average daily traffic volumes.

The overall control VMT estimate from fuel use data is based upon the tax records of the Motor Fuels Tax Bureau with adjustments for fuels not used on highways. The average mpg value is based upon a 1939 VMT value generated from a total coverage count on all road systems. This VMT divided by the motor fuel used, produced an mpg value of 13.41 . In the 1970s, the mpg estimate was updated through further traffic counts and fuel use data; since then mpg has been adjusted annually. Total VMT from the traffic counting method is then adjusted to reflect the difference from the control figure. 
New Mexico

New Mexico uses traffic count to estimate annual VMT. Forty-three permanent counters, 100 seasonal counters, and 250048 -h coverage counters cover the primary and secondary road systems over a five-year cycle. The primary and secondary road systems account for approximately 20,000 of the total 70,000 miles of road in the state. The remaining 50,000 miles of road are county and local road systems of which only a sma11 part is actually counted. A sample is used to generate ADTs for these two lesser road systems. Total VMT is based upon ADT values for each road system. The state uses fuel use data only to check trends. For example, if VMT for that year has increased as compared with the previous year, motor fuel use figures will be checked to corroborate the increase. New York

Recognizing that the use of motor fuel is a convenient basis for estimating annual statewide travel, FHWA in the early 1970 s sponsored a study to develop a method to estimate travel from fuel used. 3 This study develops average statewide fuel use rates in steps. First, a base table showing average fuel use by vehicle type and by highway operating conditions is prepared. The fuel use rate is based on pertinent factors such as speed, road grade and curvature, vehicle stops, extent of congestion, and number of grades. Originally the study estimated statespecific values for these variables in creating the base table. Second, the base table values are combined to compute average statewide fuel use. Fuel use is divided intially into four categories, one for each vehicle type. This grouping is done on the basis of proportional travel by the six highway systems. The four fuel-use categories are then combined into one statewide average on the basis of proportional travel by vehicle type.

The Claffey report computed average 1974 fuel use for eight states, including New York. ${ }^{5}$ For the remaining states, only base-table values were computed. The New York Department of Transportation has adopted the figure and has been using it without adjustment on the basis of changes through time. The total gallons of fuel is obtained from the total quantity of motor fuel consumed in New York reported in Table MF-21, an 
annual table prepared by FHWA based upon state reports of motor fuel sales passing through state taxing channels. The resulting VMT estimate is further checked against traffic count data obtained from the following sources :

- The state highway system of 15,000 miles is divided into approximately 7000 two-mile sections. Traffic counts are made on each section every three years.

- For nonstate highway systems, estimates are obtained from traffic counts in metropolitan and regional planning areas for specific projects, traffic counts in some rural areas and counties undertaken by local planning agencies, and estimates based on expert judgment for the remaining areas.

Average traffic on the major road systems is computed from flow map data constructed on the basis of about 12,000 two- or three-day counts taken annually on the state highway system. An average volume for each road system is computed and multiplied by the mileage of that system to produce a VMT estimate. The estimates are then summed for all road systems in the state. This total is checked against the total VMT estimated from fuel use data and against current regional VMT estimates prepared by the Department's urban transportation planning staff.

As would be expected, the estimate is less accurate in the lesser road categories since most of the data are derived from the state highway system which includes very few collectors and local streets and highways.

Adjustments to the VMT by functional classification are made in the lower functional classifications in order to meet exactly the total VMT estimate. Those adjustments are monitored by comparing the average volume which results from each estimate with the average volumes for the other classifications.

North Carolina

North Carolina estimates VMT by traffic counts on all road categories as well as functional classifications to obtain ADT values. VMT estimated from these ADT values is then checked against trends in registration data (known number of vehicles) and fuel use data to ascertain the reasonableness of the VMT estimate. If the VMT estimates doe not reflect trends in the other indicators, it is changed accordingly. 
North Dakota

North Dakota estimates VMT from two-day traffic counts made with small accumulating counters. These counts cover approximately one-forth of the total road mileage in the state each year. Seasonal factors are calculated from traffic counts from 60 permanent automatic recording counters which cover all road categories. A total of 5000 to 6000 counts are made annually using the portable accumulating counters. Traffic counts are then averaged for each type of road system and multiplied by the number of miles in each system to get VMT for all road systems. $\underline{\text { Ohio }}$

Ohio calculates a total control VMT by fuel use. The gallons of motor fuel used on roads is estimated from fuel tax receipts and multiplied by an average mpg value for all vehicles. VMT estimate is adjusted annually against the increase in vehicle registrations. The breakdown by road classification is estimated through the use of 50 permanent counters and 80 seasonal counters which generate representative ADTs by type of road system. However, VMT estimated by sample counts is adjusted against the total VMT estimated from fuel tax data.

Oklahoma

The VMT estimate for Oklahoma is based upon fuel tax data and an estimated mpg value for the state. The gallons used by motor vehicles is estimated from fuel tax receipts. The mpg estimate is from an empirical study made in the mid-1960s, the results of which have been verified by estimates obtained through the Claffey method. ${ }^{3}$ The mpg figures are updated annually based on vehicle registrations. To divide total VMT into VMT by road category, traffic counts are made at approximately 5000 locations two or three times annually. In addition, 48 permanent locations are monitored continuously to generate data on trends and variations. ADT values obtained from traffic counts are then converted to VMT by type of road system and added to get total VMT for the state. The two VMT estimates are then adjusted depending on the difference between them. 
Oregon

Oregon uses traffic count and fuel use to estimate total VMT. The total VMT estimate is broken down by passenger cars and various types of trucks and buses. A total control VMT is generated by estimating VMT for passenger cars and carriers separately. A 1967 fuel use study done by the state of Oregon established an mpg figure for passenger cars which is updated in proportion to changes in the national average. These data are combined with fuel use by passenger cars to estimate VMT for passenger cars. For trucks and buses, Oregon uses an mpg value based on a survey of large intrastate carriers and also data generated from the weight/mile tax which is levied on truck operators. Thus, a total control VMT for the state is established for all vehicles. Traffic count is used to divide the total VMT by road categories. For the state-administered system, total coverage is completed over a four- to five-year cycle using 2000 locations per year. An estimated ADT based on the yearly sample is used to estimate VMT on the state-administered highway system. For county roads and city streets, a 1970 sample traffic count is used to generate VMT for these road systems. Total VMT estimated by the two methods is then adjusted according to the difference between them.

Pennsylvania

Pennsylvania uses a combination of traffic count and fuel use to estimate VMT for the state. To establish a total VMT as a control figure, the number of gallons of motor fuel consumed on highways is multiplied by an average mpg value. Fuel consumed is estimated by dividing gross gallons for the year to be estimated by gross gallons from the previous year (from state records) and multiplying by highway motor fuel used as reported in Table MF-21 of Highway Statistics for the previous year. The mpg value, which has remained static from 1971 through 1975, is updated according to a 1952 motor vehicle use study and current motor vehicle registrations by type of vehicle.

The division of VMT by road categories is based on ADTs established over a three-year cycle of sample traffic counts over the interstate 
and state-administered road systems. The ADT for other federal-aid local road systems is assumed to be the same as the ADT for the federal-aid secondary systems. VMT, estimated by traffic count, is then compared with the control VMT and adjustments are made using the locally owned nonfederal-aid systems.

Rhode Island

Rhode Island's road system is small compared with most states, and all roads are classified either as primary or local. On state-administered roads, automatic traffic counters on sample section lengths generate an ADT for primary roads. For local roads, ADTs are determined from vehicle classification counts done manually. As in most other states, VMT is calculated by multiplying the ADT by the number of miles in that particular road system, and state VMT is the sum of VMTs for all road systems.

South Carolina

South Carolina estimates VMT from fuel tax receipts and an estimated mpg value. The mpg value is based upon a trend curve developed in the early 1970s, and the value used is slightly higher than that reported by the Federal Highway Administration. The state is presently undertaking research to update the mpg value according to vehicle weight. The VMT estimated from fuel use is tested by sample traffic counts (every two years for federal and state and every five years for local and secondary) and ADTs for each road classification. Generally, differences between the two estimates have been in the $10 \%$ range which is considered too high and, therefore, VMT estimates based upon traffic counts are adjusted to reflect more closely VMT estimated from fue 1 use data.

South Dakota

South Dakota has for the past 14 years relied on a base-year estimate of total VMT established in 1963. At that time, an extensive counting program was carried out and covered all road types by county and cities of over 5000 population, establishing ADTs for all road categories. 
Annual updates are made from counts from 60 permanent counters on a11 types of roads which are used to factor yearly variations by road type. The new base year will be 1979 once tabulation and printing is completed. South Dakota plans to establish base years through extensive sample traffic counts every five years.

Tennessee

Tennessee estimates annual VMT from fuel tax receipts and traffic data. The total annual VMT is calculated from the fuel used (estimated from tax receipts) and an average mpg value. Fuel use is estimated from fuel tax receipts; the mpg value is computed from the 1975 Tennessee Transportation Needs Study. All values for Interstate Rural and Interstate Urban are actual VMT. Forty counties were selected and actual VMT was measured for FAP Rural, FAB Urban, Other State Rural, and Other State Urban. These calculations were then expanded to 95 counties for these systems. The FAS Rural, FAU, Local Rural, and Local Urban were computed from the remainder of the total annual VMT. Random counts from 83 continuous automatic traffic recorders were used to establish factors for 7800 short counts, covering al1 systems throughout the state. The distribution of the remaining VMT for the above systems was made using these factors.

Texas

Texas uses traffic count to estimate VMT. Traffic on state-administered highways is counted annually by 150 permanent counters and 30,000 short counts. An average ADT per mile is generated from the sampling and projected to estimate annual traffic flow per highway system. County roads are counted in five-year cycles. Approximately 20,000 counts are used as a sample to generate ADT per mile which is extended to an average ADT per highway system. Urban areas with a population of $50,000+$ are counted when it is expected that total VMT might have changed. Otherwise, city street counts are generated from whatever base year they may have been originally done, and assumed growth rates for other systems are applied to urban streets. 
$\underline{\text { Utah }}$

Utah estimates total VMT for the state according to the Federal Highway Administration's guidelines and procedures. Portable yearly counters are switched over a five-year cycle to complete a total coverage traffic count of all road categories. In addition, statistically selected sections of highways and roads are counted for traffic volume to provide adjustment factors. ADTs for all road categories are compiled and used to estimate the state's VMT.

Vermont

Vermont makes total coverage counts on all road systems in the state within two broad categories. Approximately $20 \%$ of the road mileage falls into the federal and state highway system which is divided section lengths and totally counted over a two-year cycle at the rate of 700 locations annually. In the middle of the cycle, ADT estimates provide updating information for the previous year's estimates. The second category includes local and county roads, grouped by surface type and use (such as recreational or farm-to-market) and completely counted over a four-year cycle from approximately 300 to 400 locations annually. Both traffic counting systems generate ADTs by road categories; these ADTs are then used to calculate VMT by road categories, the sum of which is the total VMT for the state.

Virginia

VMT estimates for Virginia on the interstate and primary system are based on 5400 regularly scheduled classification counts which include seasonal counts, and Saturday, Sunday, and night counts to estimate ADT for the interstate and primary routes. VMT is then estimated from the ADT and miles of road.

Regularly scheduled traffic counts are made of the secondary system by accumulative, nondirectional automatic recorders for one 24 -h period every other year. Recorders are placed on each section of each secondary route in each county biennially. From the recorder counts the ADT is estimated. VMT is estimated for each county from ADT and miles of road. 
The total VMT estimate from traffic counts is checked against a VMT estimate from motor fuel tax receipts and an estimated mpg value for the state.

Washington

Washington uses traffic count to estimate total VMT. But of the 80,000 miles of public highways, VMT is estimated for only 60,000 . The other 20,000 are on military installations, Indian reservations, and mountainous roads which are considered to have negligible traffic and are not reported at all. Fifty percent of VMT is on 7000 miles of interstate, federal and state primary systems and is counted by 45 permanent counters of which approximately 10 are semipermanent. Also, annual 48-h counts are taken with 50 portable counters. This composite is used as a sample to generate ADT per section which is averaged out to obtain an ADT per highway system. Twenty-five percent of VMT is on county roads. The traffic count for county roads was done during 1969-75 when all roads were divided into four-mile sections and volume computed and averaged out by surface type to give an ADT by surface type. Twenty-five percent of VMT is on city streets, but there is no uniform method used to calculate the total. There is some use of city flow maps, Highway Department counts, and estimates from studies.

West Virginia

Traffic is counted annually on interstate, U.S. and state routes. The county route system is counted in five-year cycles with approximately $20 \%$ (eleven counties or two districts) of the state being counted each year. This schedule includes approximately 3000 total counts being made yearly. At this time there is no specific planning or scheduling of counts by functional system, rural-urban system, or by federal-aid system other than on interstate. The statewide counting program is oriented to rural routes, with few counts taken on city or municipal streets; the exception to this is those cities or municipalities included in urban transportation studies where annual counts are made. These counts are on the study area network only, and are consistent with procedures in the "Guide for Urban Traffic Volume Counting." Each year all of these counts are used to update ADTs for all road segments. 
VMT estimates are then generated directly from the AADT for the latest year counted. From the increase in vehicle-miles of travel for the county routes counted in any particular year, growth factors are developed and applied to the county routes which were not counted in that year, that is, the factors are applied to the last counted or estimated traffic volume for those routes. Since county routes are counted in a five-year cycle, some routes are projected four years, some three years, some two years, and some only one year. These factors are applied to the road inventory $\log$ to create a traffic count file for the particular year. Each year, as new counts are collected, traffic for routes in uncounted counties is reestimated. Routes counted each year (i.e., interstate, U.S., and state routes) are updated continuously as counts are collected and compiled.

Wisconsin

The estimating of vehicle-miles traveled by highway system is based partly on actual traffic counts and partly on motor fuel use records. The first step is to determine a statewide control total by estimating VMT from total annual fuel use. An average mpg is determined by adjusting Wisconsin's previous year's average mpg either up or down, based upon a comparison of the growth rates of the statewide fuel consumption with traffic counts at about 60 automatic traffic recorders.

The next step is to obtain computer compilations of VMT where traffic counts have been made. Then, after subtracting the known VMT from the statewide estimated total, the remaining VMT is allocated among the remaining road systems based upon expected traffic volumes for such classifications.

Wyoming

Total VMT for Wyoming is estimated by traffic count. Fifty-seven permanent counters are used on the 6695 miles of road in the state to estimate annual ADTs by road category. While in the past the state did additional annual sample counts at different locations to update or adjust the ADT estimated by the permanent recorders, this has not been done recent1y. 


\section{STATISTICAL ANALYSiS OF STATE VMT ESTIMATES}

Since states use different methods for estimating annual VMT, the question naturally arises as to whether these different methods produce systematically different estimates. Does the fuel use method produce consistently higher (or lower) estimates than the traffic count method? Which method is associated with the highest variability of estimates from one year to the next? If systematic differences do exist, they would have to be included in any analysis of VMT data. However, a lack of significant differences would argue that all existing VMT statistics are equally valid, regardless of the method of estimation. Furthermore, if two very different estimation methods arrive at estimates which are statistically indistinguishable from one another, presumably VMT statistics are not as error prone as many have suggested.

To shed some light on these questions, the Oak Ridge National Laboratory analysed the state VMT statistics for differences among the three methods identified in the TERA report: (1) traffic count, (2) fuel use, and (3) a combination of VMT estimates generated by methods (1) and (2). Based on the descriptions of state estimation procedures contained in the TERA study, states were put into one of the three categories (Table 9). The major statistical technique used was an analysis of covariance on the three subgroups for the period 1966-1975. This was supplemented by an analysis of selected descriptive statistics for each state.

One question concerning this analysis cannot be definitively answered here. It is whether the differences identified are directly attributable to the method of estimation used or whether it just happens by chance that the groups of states using different methods are intrinsically different in their travel behavior. Among methods tried, the analysis of covariance, in that it corrects for relevant state characteristics, comes closest to answering this question. 
Table 9. States by Method of Estimating Vehicle-Miles of Trave1

\begin{tabular}{|c|c|c|}
\hline Traffic count & Fuel use & Combined \\
\hline Alabama & Alaska & California \\
\hline Arkansas $^{\alpha}$ & Arizona & Indiana \\
\hline Colorado & Connecticut & Kentucky \\
\hline Delaware & Hawaii & Mississippi \\
\hline D. C. & Idaho & Missouri \\
\hline Florida & Illinois & Nebraska \\
\hline Georgia & Maine & New Hampshire \\
\hline Iowa $^{a}$ & Michigan & New Jersey \\
\hline Kansas & Montana & New York ${ }^{\alpha}$ \\
\hline Louisiana & Ohio & North Carolina \\
\hline Maryland & Tennessee $^{a}$ & Oklahoma \\
\hline Massachusetts & & Oregon \\
\hline Minnesota & & Pennsylvania \\
\hline Nevada & & South Carolina \\
\hline New Mexico & & Virginia \\
\hline North Dakota & & Wisconsin \\
\hline \multicolumn{3}{|l|}{ Rhode Island } \\
\hline \multicolumn{3}{|l|}{ South Dakota } \\
\hline \multicolumn{3}{|l|}{ Texas } \\
\hline \multicolumn{3}{|l|}{ Utah } \\
\hline \multicolumn{3}{|l|}{ Vermont } \\
\hline \multicolumn{3}{|l|}{ Washington } \\
\hline \multicolumn{3}{|l|}{ West Virginia } \\
\hline Wyoming & & \\
\hline
\end{tabular}




\subsection{Descriptive statistics}

As a first step, total VMT and mpg (VMT $\div$ highway motor fuel sales) were estimated by state for the period 1966-1975. The VMT statistics by state showed a wide range in mean values (from $1.4 \times 10^{9}$ for Alaska to $117.4 \times 10^{9}$ for California). In the analysis of covariance, state VMTs were divided by the number of households in the state to produce a number comparable across states.

States using fuel use or combined techniques to estimate VMT estimate an average state mpg. Those states using traffic count exclusively, derive mpg values from the estimated VMT and actual motor fuel sales data. To determine if states which calculated mpg directly had less variability in this value from 1968 to 1975 than those that did not, a simple nonparametric test, the Krushkal-Wallis $H$ test, was used to test the hypothesis that the coefficient of variation (the standard deviation as a percent of the mean) was greatest for states using the traffic count method. The results, significant at the 0.01 level, showed that the variability of mpg values derived from traffic count estimates was greater. This result is not surprising, and suggests a greater inherent variability in the traffic count method.

\subsection{Analysis of covariance}

An analysis of covariance, rather than an analysis of variance, was judged to be the appropriate method to identify differences among the three groups of states. This procedure (analysis of covariance) is preferred because it allows the levels of state VMT per household to vary with state income, highway motor fuel prices, and other relevant factors. Correcting for these important influences makes it possible to more accurately identify the differences attributable solely to group membership. 6

The analysis of covariance was done with three different linear models. The first model [Eq. (1)] simply expresses a state's current VMT as a function of last year's VMT and a constant term: 


$$
\mathrm{VMT}_{t}=a+\text { VMMT }_{t-1},
$$

where $a$ and $b$ are constants and $t$ is the time period. However, the model is quite crude since it permits VMT to change only monotonically over time. Monotonic increases in VMT depend on the value of $b$ for $a>0$ if $b$ is sufficiently large (Fig. 4). But a significant decline in VMT occurred in virtually all states during the period of rapidly rising prices accompanying the oil embargo of 1973-1974. The estimated values of $b$ in model 1 are close to 0.8 , apparently a reflection by the model of this dip in VMT.

Mode1 2 [Eq. (2)] is far superior to mode1 1 in this regard since it expresses VMT as a function of gasoline prices and income levels as we11 as lagged VMT:

$$
\mathrm{VMT}_{t}=a+b \mathrm{VMT}_{t-1}+c Y+d P
$$

where $c$ and $d$ are again constants, $Y$ is household disposable income, and $P$ is the price of gasoline (the last two in constant dollars). Equation (2) is in fact a special case of a dynamic demand equation. ${ }^{7}$ For this study it is preferable to model 1 because it permits VMT to decline with rising prices and stagnating income and then to increase as prices stabilize and income rises.

Model 3 [Eq. (3)] eliminates the lagged VMT variable and expresses current VMT as a linear function of several relevant variables:

$$
\mathrm{VMT}=a+b Y+c P+d C+e D+f S+g P D+h T+i M
$$

where $a-i$ are constants and $C$ is number of cars per household, $D$ is drivers per household, $S$ is household size, $P D$ is population density, $T$ is number of trucks per household, and $M$ is the percent of the population living in metropolitan areas. This model has the advantage of relating VMT to 
ORNL-DWG 78-2442

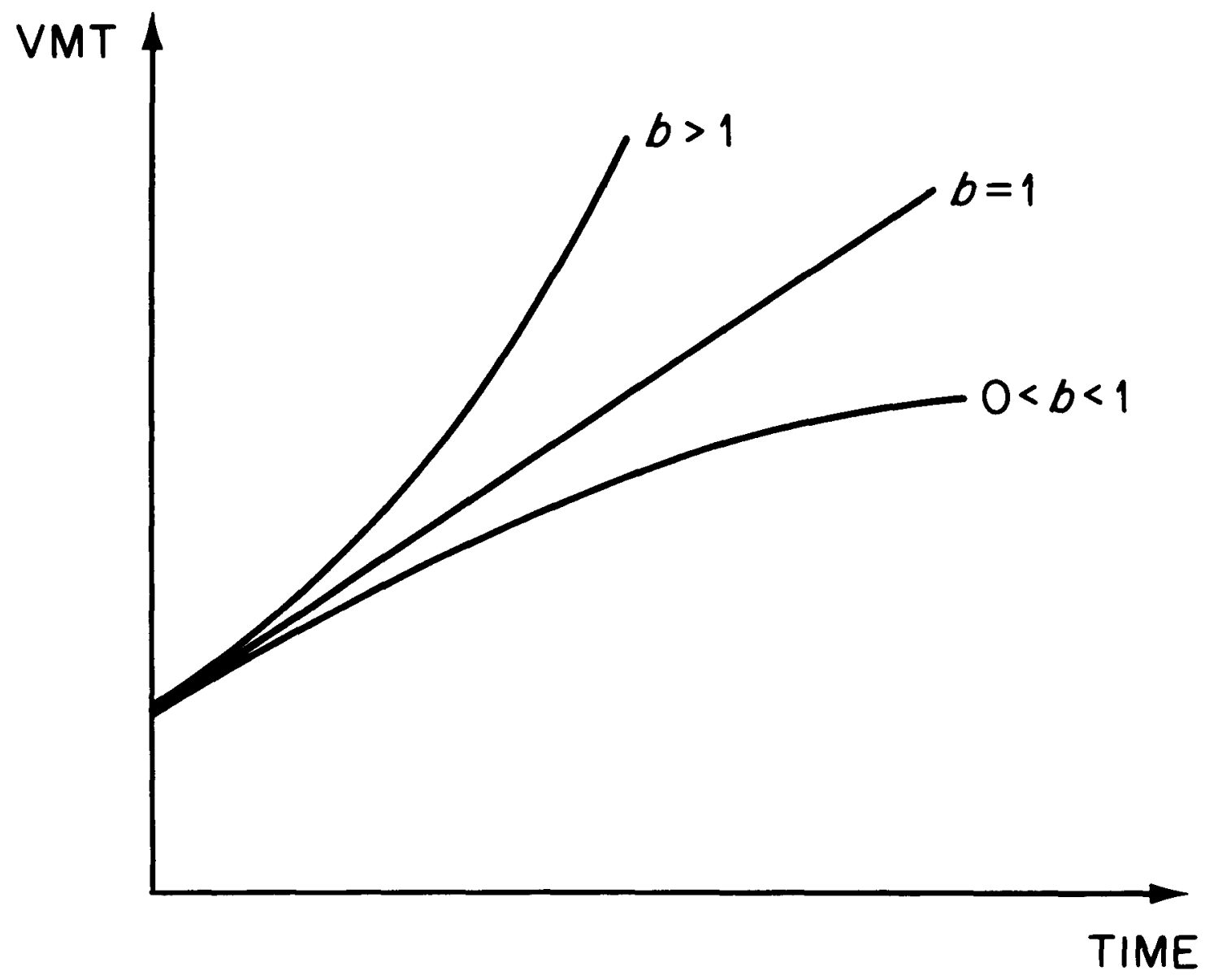

Fig. 4. Dependence of Rate of Increase of VMT (Model 1) on the Value of $b$. 
a variety of factors which vary across states and over time. In general, models 2 and 3 were superior to model 1 for the analysis of covariance.

In all three models, dummy variables were introduced to account for state-specific influences not accounted for by the variables included in the equations. This technique, known as the least squares dummy variable (LSDV) technique, is a standard econometric method for analyzing a time series of cross-sectional data. Under certain conditions, closely approximated by our data, the LSDV approach is equivalent to a more sophisticated generalized least squares technique known as variance component analysis. ${ }^{8}$ However, the variance component approach could not be used for an analysis of covariance.

Several states had to be excluded from the analysis because they changed their estimation procedure during the period under study. For this reason Arkansas, Iowa, and Tennessee were omitted. Alaska and Hawaii were omitted because gasoline price data were not available for these states.

The analyses of covariance for the three models (Tables 10-12) show consistent patterns across all models. In general, the improvement in explanatory power gained by estimating separate equations for each group (instead of a pooled estimation with dummy variables for each group) is not significant. The exception is model 3 [Eq. (3)] where estimating separate regressions gives an improvement significant at the 0.05 level (the appropriate test statistic is $F_{2}$ ). On the other hand, the addition of group dummy variables to the pooled regression produces a significant improvement in explanatory power for every model ( $F_{1}$ is the relevant test statistic). These results imply that there are indeed differences in state estimates using different estimation techniques. The results indicated that the group estimates certainly differ by a constant term but are inconclusive, although generally negative, about whether the relationships between estimates and model variables differ.

Use of the dummy variable coefficients indicates that the constant differences among groups is enough that states using the fuel consumption method have household annual VMT estimates 200-500 miles per year higher than states using the traffic count method. Those states comparing traffic 
Table 10. Analysis of Covariance Sums of Squares and Test Statistics for Model 1

\begin{tabular}{|c|c|c|c|c|}
\hline Source & SSE & d.f. & MSE & F values \\
\hline Pooled regressions & $134199789.99^{a}$ & 369 & 363685.0677 & \\
\hline \multicolumn{5}{|l|}{ Pooled regressions } \\
\hline With group & $126987203.03^{\alpha}=S_{2}$ & 367 & 346014.177 & $F_{1}=10.42$ \\
\hline Dummy variables & $7212586.96^{b}=S_{1}$ & 2 & 3606293.48 & $F(2,367) \doteq 3.00$ \\
\hline \multirow[t]{4}{*}{ Separate regressions } & $126957705.62^{\alpha}=S_{4}$ & 365 & 347829.31 & $F_{2}=0.04$ \\
\hline & $29497.41^{b}=S_{3}$ & 2 & 14748.705 & $F(2,365) \doteq 3.00$ \\
\hline & & & & $\mathrm{F}_{3}=5.21$ \\
\hline & & & & $F(4,365) \doteq 2.37$ \\
\hline
\end{tabular}


Table 11. Analysis of Covariance Sums of Squares and Test Statistics for Mode1 2

\begin{tabular}{|c|c|c|c|c|}
\hline Source & SSE & d.f. & MSE & $\mathrm{F}$ values \\
\hline Pooled regressions & 100221153.11 & 367 & 273082.1611 & \\
\hline \multicolumn{5}{|l|}{ Pooled regressions } \\
\hline With group & $91092272.31^{a}=S_{2}$ & 365 & 249567.8694 & $\mathrm{~F}_{1}=18.29$ \\
\hline Dummy variables & $9128880.80^{b}=\mathrm{S}_{1}$ & 2 & 4564440.4 & $F(2,365) \doteq 3.00$ \\
\hline \multirow[t]{4}{*}{ Separate regressions } & $89591404.56^{a}=S_{4}$ & 359 & 249558.23 & $\mathrm{~F}_{2}=1.002$ \\
\hline & $1500867.75^{b}=\mathrm{S}_{3}$ & 6 & 250144.625 & $\mathrm{~F}(6,359) \doteq 2.80$ \\
\hline & & & & $\mathrm{F}_{3}=5.32$ \\
\hline & & & & $F(8,359) \doteq 2.51$ \\
\hline
\end{tabular}

$a_{\text {Residual. }}$

${ }^{b}$ Incrementa1. 
Table 12. Analysis of Covariance Sums of Squares and Test Statistics for Mode1 3

\begin{tabular}{|c|c|c|c|c|}
\hline Source & SSE & d.f. & MSE & F values \\
\hline Pooled regressions & $134255166.69^{\alpha}$ & 362 & 370870.6262 & \\
\hline \multicolumn{5}{|l|}{ Pooled regressions } \\
\hline With group & $126536255.05^{\alpha}=S_{2}$ & 360 & 351489.5974 & $F_{1}=10.98$ \\
\hline Dummy variables & $7718911.64^{b}=S_{1}$ & 2 & 3859455.819 & $F(2,360) \doteq 3.00$ \\
\hline \multirow[t]{4}{*}{ Separate regressions } & $112115670.42^{a}=S_{4}$ & 344 & 325917.65 & $\mathrm{~F}_{2}=2.77$ \\
\hline & $14420584.7^{b}=S_{3}$ & 16 & 901286.5438 & $\mathrm{~F}(16,344) \approx 1.65$ \\
\hline & & & & $\mathrm{F}_{3}=3.77$ \\
\hline & & & & $F(18,344) \doteq 2.00$ \\
\hline
\end{tabular}

$a_{\text {Residual. }}$

$b_{\text {Incremental. }}$ 
count and fuel consumption estimates to arrive at a combined estimate tend to be 750-1500 miles per year lower than states using the traffic count method alone. These differences were statistically significant at the 0.051 eve 1 in all cases except the fuel consumption dummy in model 3 [Eq. (3)].

The interpretation of these dummy variables requires some explanation since LSDV estimation requires a dummy variable for each state. The use of dummy variables to account for state effects for all states would lead to perfect linear dependence between the state dummies of a group and the group dummy unless one state dummy were omitted in each group. As a result, the state effect (dummy variable coefficient) will be incorporated in the group dummy. However, its magnitude will be reduced by a factor of $\frac{1}{m}$, where $m$ is the number of states in the group. Choosing a state whose dummy variable was not significantly different from zero by itself ensured that the influence of omitting the state dumny on the group dummy would be negligible.

In summary, differences were found among the three estimation methods. However, estimates generated by the three methods seem to bear the same relationships to explanatory variables, especially lagged VMT, income, and fuel price. That is, the estimates seem to be about equally responsive to changes in explanatory factors. This finding is significant in itself since it indicates a degree of consistency among the three methods. The difference between the approaches is in the group dummy variables which represent differences in model equation intercepts but not slopes across the three groups. In general, the difference between the fuel use and traffic count methods is smal1. With model 3 [Eq. (3)] the difference is not even significant. There is a big difference between the combined estimation procedure and the other two methods. The dummy for the combined approach is significant in every model at the 0.05 level. It is usually four to five times as large in absolute value as the dummy for the fuel use method, ranging between 5 and $8 \%$ of the overall national average VMT per household. That this dummy is negative is somewhat puzzling. It is not obvious why states which combine methods should produce generally lower estimates than those using exclusively one or the other. 
There appear to be two possible explanations for the lower VMT estimates produced by states using the combined method. First, it could be that by chance the states using this method happen to have lower VMTs per household and lower rates of VMT growth than the other states because of some factor that was not captured with either of the three models. If this hypothesis is accepted, it implies that there are, in fact, no important differences among the three methods of estimating VMT. However, casual inspection of the 1 ist of states in each group does not seem to support this hypothesis. Secondly, it may be that somewhere in the process of comparing traffic count and fuel use there is a downward bias. Because of the limited descriptions of state methods available, it is not possible to identify a possible source for such a bias.

In any event, it appears that the systematic differences between estimating methods, if any, are less than $10 \%$ of average national household VMT. More importantly for future analysis of VMT data, there appear to be no important differences in the way VMTs estimated by the three methods respond to price and income changes at the state level. This consistency among estimation procedures suggests a general validity of state-level VMT statistics.

\subsection{Variability of VMT estimates}

The analysis of covariance compares the conditional means of groups, correcting for the effects of other factors which influence the level of VMT. Also compared is the variability, or inherent noise, in the estimates produced by the three methods. It is useful to know which procedures produce estimates with the lowest variability. The mean squared errors (MSE) of the separate regressions in the analysis of covariance provide indices of the inherent variability of the estimating procedures. F tests for equality of variances were done for all three models (Table 13). Once again, model 1 [Eq. (1)] contains only lagged VMT and a constant; model 2 [Eq. (2)] adds gasoline price and income, while model 3 [Eq. (3)] contains no lagged dependent variable but adds a group of other relevant factors. If the ratio of MSE exceeds the value of $F$ 
Table 13. Tests for equality of variance of error in models 1-3

\begin{tabular}{|c|c|c|c|c|}
\hline Group & $\begin{array}{c}\text { Mean squared } \\
\text { errors }\end{array}$ & $\begin{array}{l}\text { Degrees of } \\
\text { freedom }\end{array}$ & $\begin{array}{l}\text { Comparison } \\
\text { and test } \\
\text { statistic }\end{array}$ & $\begin{array}{c}\text { Value of } F \\
\text { for } \\
\alpha=0.05\end{array}$ \\
\hline \multicolumn{5}{|c|}{ Mode1 $1^{a}$} \\
\hline Traffic count & 384757.57 & 175 & $\mathrm{~S}_{1}^{2} / \mathrm{S}_{2}^{2}=1.27$ & $F(175,127)=1.43$ \\
\hline Fuel use & 335016.88 & 63 & $\mathrm{~S}_{3}{ }^{2} / \mathrm{S}_{2}{ }^{2}=1.10$ & $F(63,127)=1.53$ \\
\hline Combined & 335016.88 & 127 & $\mathrm{~S}_{1}^{2} / \mathrm{S}_{3}^{2}=1.15$ & $F(175,63)=1.58$ \\
\hline \multicolumn{5}{|c|}{ Mode1 $2^{b}$} \\
\hline Traffic count & 321138.10 & 173 & $S_{1}^{2} / S_{2}^{2}=1.80$ & $F(173,125)=1.43$ \\
\hline Fuel use & 192250.02 & 61 & $\mathrm{~S}_{3}{ }^{2} / \mathrm{S}_{2}{ }^{2}=1.08$ & $F(61,125)=1.53$ \\
\hline Combined & 178458.10 & 125 & $\mathrm{~S}_{1}^{2} / \mathrm{S}_{3}^{2}=1.67$ & $F(173,61)=1.58$ \\
\hline \multicolumn{5}{|c|}{ Mode1 $3^{c}$} \\
\hline Traffic count & 375011.39 & 168 & $\mathrm{~S}_{1}^{2} / \mathrm{S}_{2}^{2}=1.28$ & $F(168,120)=1.43$ \\
\hline Fuel use & 247375.40 & 56 & $\mathrm{~S}_{2}^{2} / \mathrm{S}_{3}^{2}=1.19$ & $F(120,56)=1.48$ \\
\hline Combined & 247375.40 & 120 & $S_{1}^{2} / s_{3}^{2}=1.52$ & $F(168,56)=1.58$ \\
\hline
\end{tabular}

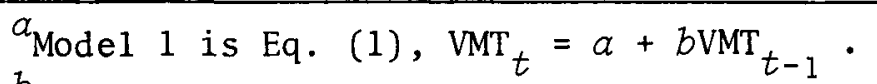

$b_{\text {Mode1 }} 2$ is Eq. (2), $\mathrm{VMT}_{t}=a+b \mathrm{VMT}_{t-1}+c Y+d P$.

${ }^{c}$ Model 3 is Eq. (3), VMT $=a+b Y+c P+d C+e D+f S+g P D+h T+i M$. 
(Table 13), then the MSE in the numerator is significantly greater than that in the denominator at the 0.05 level of significance for a twotailed test.

Thus, for mode1 1 [Eq. (1)] there are no significant differences in variability among the groups. In model 2 [Eq. (2)] the variability of estimates produced by states using the traffic count method is significantly greater than that for either of the other methods. For mode1 3 [Eq. (3)] there are once again no significant differences at the 0.05 level, though $\mathrm{S}_{1}^{2}>\mathrm{S}_{2}^{2}$ at the 0.06 level. However, in every instance the variability for the traffic count method is largest (even though the differences may not be statistically significant at the 0.05 level). These results generally corroborate the results of the nonparametric tests conducted above.

It would seem reasonable to infer from the above that the traffic count method has a greater variability. No doubt this is partly because many states use the same calculated or assumed mpg figure to estimate VMT from one year to the next. Thus it is not fair to conclude that the traffic count method is subject to greater errors. In fact, it may instead be more sensitive to actual changes in VMT than the fuel use method.

\subsection{Conclusions}

This analysis of VMT statistics tends to support three important conclusions about state VMT estimates:

1. Estimates produced by traffic count show a greater variability than those produced by the other two methods (though this does not necessarily indicate that the method has a greater inherent error).

2. States using a combination or comparison of traffic count and fuel use methods arrive at consistently lower estimates of annual VMT per household, other things being equal, than states using exclusively one or the other.

3. Despite the above differences, there are no significant differences among groups in the relationship of a given year's 
VMT estimate to state income, gasoline prices, and the previous year's VMT estimate. This consistency of relationships across groups should be encouraging to those using state VMT statistics in analytical studies.

Although these conclusions are generally positive, serious questions still remain about the validity of state VMT statistics. While the three groups of states may be reasonably consistent on the average in terms of their estimates, individual states might still be way off. If these states are randomly distributed among the three groups, there would be no way for this analysis to detect their large errors; nor is this a sufficiently detailed analysis of the estimated error terms of the models to be able to draw conclusions about the average errors of state VMT estimates. Further analysis should be done in this area.

While this study represents some progress in the analysis of the validity of state VMT estimates, it also underlines the need to improve the quality of state VMT estimates. The differences discovered among estimation procedures suggest that a uniform estimating method should be adopted by all states. However, this method should be carefully designed to minimize errors and still provide sensitivity to changes in travel activity. Odometer surveys are often mentioned as a panacea to the VMT problem. They have the tremendous design advantage; unfortunately, they would not actually measure VMT within a state but rather VMT by vehicles registered in the state. Out-of-state travel by in-state vehicles and travel within the state by out-of-state vehicles would be unmeasurable. Thus there is no panacea to the problem of VMT estimates. The selection of the best estimating method will require further, careful study. 


\section{REFERENCES}

1. U.S. Bureau of the Census, Census of Transportation, 1972, Truck Inventory and Use Survey, U.S. Surmary, U.S. Government Printing Office, Washington, D.C., 1973, Table 2.

2. Ibid., Appendix A, p. 2 .

3. Paul J. Claffey, Travel Estimates from Fuel Consumption Information, Report No. DOT-FH-11-7833, prepared for FHWA, Office of Highway Planning, Washington, D.C., 1972.

4. American Public Transit Association, Transit Fact Book, 1975-76 ed., Washington, D.C., Table 10, p. 36.

5. Paul J. Claffey, op. cit., Table 17, column 5, p. 43.

6. J. Johnston, Econometric Methods, McGraw-Hi11, Inc., New York, 1972, pp. $192-207$.

7. H. S. Houthakker and L. D. Taylor, Consumer Demand in the United States, 1929-1970, Harvard Univ. Press, Cambridge, MA, 1966, p. 25.

8. G. S. Madalla, "The Use of Variance Components Mode1s in Pooling Cross Section and Time Series Data," Econometrica, 39(2):341-58, 1971. 
$$
\text { . }
$$ 
STATE OFFICIALS CONTACTED CONCERNING TERA VMT DATA

\section{State}

Alabama

Alaska

Arizona

Arkansas

California

Colorado

Connecticut

\section{Officials}

David Truett, Chief

Bu. of Plan. \& Programming

State Highway Department

State Highway Building

Montgomery 36104

John L. Umlauf

Trans. Plan. Dir.

Dept. of Trans. \& Pub. Fac.

P. O. Box 1467

Juneau 99801

John A. Bivens, Asst. Dir.

Trans. Planning Div.

Arizona Dept. of Trans.

206 South 17th Avenue

Phoenix 85007

A. E. Johnson, Jr., Engr.

Div. of Plan. \& Res.

Arkansas State Hwy. and

Transportation Dept.

P. 0. Box 2261

9500 New Benton Hwy.

Little Rock 72203

Jack Kassel, Act. Chief, Div. of Trans. Planning

Calif. Dept. of Trans.

1120 N. Street

Sacramento 95814

Glenn W. Fritts

Plan. E Res. Engr.

Plan. \& Res. Div.

Department of Highways

4201 East Arkansas Ave.

Denver 80222

John Drake

Director of Plan.

$\mathrm{Bu}$. of Plan. \& Res.

Conn. State Dept. of Trans.

24 Wolcott Hill Road

Wethersfield 06109 
$\underline{\text { State }}$

Delaware

District of Columbia

Florida

Georgia

Hawaii

Idaho

Illinois

\section{Officials}

Chief Planning Engr. Office of Planning Dept. of Hwys. \& Trans., Trans. \& Public Safety Administration Building P. 0. Box 778

Dover 19901

James Clark, Asst. Dir. Off. of Trans. Policy \& Plans

Dept. of Transportation Pressidential Bldg., Rm. 519 41512 th St., N.W. Washington 20004

W. N. Lofroos, Chief Bureau of Planning Florida Dept. of Trans. Haydon Burns Bldg. Tallahassee 32304

F. L. Breen, Director Div. of Plan. \& Prog. Ga. Dept. of Trans. No. 2 Capitol Square At lanta 30334

Henry Uehara, Head Plan. Engr., Land Trans. Br. Hawaii Land Trans.

Facilities Division Department of Trans. 869 Punchbowl Street Honolulu 96813

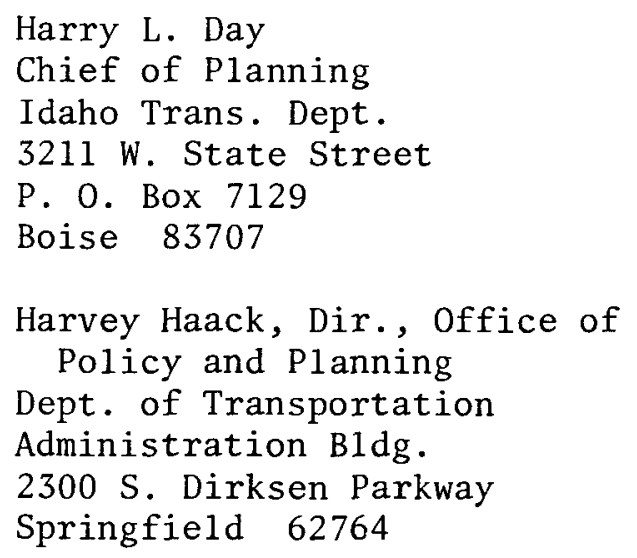


State

Indiana

Iowa

Kansas

Kentucky

Louisiana

Maine

Maryland

\section{Officials}

Walter H. Frick, Asst.

Chief Engr., Hwy. Develop.

Indiana State Hwy. Comm.

State Office Building

100 No. Senate Avenue

Indianapolis 46204

Ian MacGillivray, Dir., Plan.

$\xi$ Research Division

Iowa Dept. of Trans.

800 Lincoln Way

Ames 50010

Verne L. Craig, Engr. of

Plan. \& Dev.

Plan \& Dev. Dept.

Kansas Dept. of Trans.

State Office Building

Topeka 66612

E. B. (Bas) Gaither, Jr. Trans. Plan. Engr., Off. of Trans. Plan.

Kentucky Dept. of Trans.

State Office Building

Ann Street

Frankfort 40601

Grady Carlisle

Traffic \& Plan. Engr.

Louisiana Dept. of Trans.

and Development

Office of Highways

Capitol Station

P. 0. Box 44245

Baton Rouge 70804

Daniel Webster, Jr.

Director, Bu. of Trans. Plan. ६ Services

Maine Dept. of Trans.

State House

Augusta 04330

Clyde Pyers, Director

Division of Systems Plan. \& Dev., Maryland Dept.

of Transportation,

P. 0. Box 8755 , Baltimore -

Washington International Airport

Baltimore 21240 
$\underline{\text { State }}$

Massachusetts

Michigan

Minnesota

Mississippi

Missouri

Montana

Nebraska

\section{Officials}

Thomas F. Humphrey, Dir. Bureau of Transportation Planning \& Development Mass. State Dept. of Public Works 100 Nashua St.

Boston 02114

Sam Cryderman, Dep. Dir. of

Transportation Planning

Michigan Dept. of State Hwys.

State Highways Building

425 W. Ottawa

Lansing 48909

Harry Reed, Deputy Commissioner Bureau of Policy \& Plan.

Minnesota Dept. of Trans. Transportation Building

St. Paul 55155

Lowel1 T. Livingston, Trans. Planning Engineer Transportation Planning Div. Miss. State Hwy. Department Highway Laboratory Bldg. 412 Woodrow Wilson Ave.

P. O. Box 1850

Jackson 39205

Car1 E. Klamm, Div. Engr., Planning

Missouri State Hwy. Comm.

State Highway B1dg.

119 West Capitol

Jefferson City 65101

James W. Hahn, Chief

Plan. \& Research Bureau

Department of Highways

East 6th Ave. \& Roberts St.

Helena 59601

C. F. Nutter, Dep. St. Engr. for Engineering Services Department of Roads

P. O. Box 94759

Lincoln 68509 
State

Ohio

Ok1ahoma

Oregon

Pennsylvania

Rhode Island

South Carolina

South Dakota

\section{Officials}

Russe11 E. Catlin

Chief Engineer Plan. \& Design

Ohio Department of Trans. Department of Trans. Bldg. 25 S. Front Street

Columbus 43215

M. C. Murphy, Asst. Dir.

Planning and Research

Oklahoma Department of Trans.

Oklahoma Dept. of Trans. Bldg.

$200 \mathrm{NE} 21 \mathrm{st}$ Street

Oklahoma City 73105

Larry W. Rulien, Asst. Dir.

for Policy \& Program Dev.

Oregon Dept. of Trans.

State Trans. Building

Salem 97310

James B. Chiles, Dep. Secy. for Planning

Dept. of Transportation

Trans. \& Safety Building

Forster Street

Harrisburg 17120

Joseph F. Arruda, Act. Chief of Transportation Planning Division of Planning Dept. of Transportation State Office Bldg., Smith St. Providence 02903

William T. Young, Traffic \& Planning Engineer

S.C. Dept. of Hwys. \& Public Transportation 1100 Senate Street

Columbia 29202

Eugene L. Rowen, Dep. Secretary for Policy Development and Evaluation

Dept. of Transportation

Pierre 57501 
$\underline{\text { State }}$

Tennessee

Nevada

New Hampshire

New Jersey

New Mexico

New York

North Carolina
Officials

Paul Edens, Director Office of Res. \& Plan. Department of Transportation Transportation Building Nashville 37219

George B. Westenhoefer, Chief Plan. Survey Engr.

Plan. Survey Division Nevada Department of Hwys. State Highway Building 1263 South Stewart Street Carson City 89712

Robert G. Kenevel, Plan. \& Economics Engineer Plan. E Economics Div. New Hampshire Dept. of Public Works \& Highways John 0. Morton Building

Concord 03301

Keith Rosser, Dir. of Trans. Plan. \& Res. New Jersey State Dept. of Transportation 1035 Parkway Avenue Trenton 08625

A. W. Gonzales Planning Director, Plan. \& Programing Division New Mexico State Hwy. Dept. 1120 Cerrillos Road

Santa Fe 87502

John K. Mladinov, Asst. Comm. for Plan. \& Dev. Office of Plan. \& Dev. of Transportation 1220 Washington Ave. Albany 12232

T. L. Waters, Manager of Planning and Research Division of Highways North Carolina Dept. of Trans. \& Highway Safety State Highway Building Raleigh 27611 
$\underline{\text { State }}$

North Dakota

Texas

Utah

Vermont

Virginia

Washington

West Virginia

Wisconsin
Officials

Duane R. Bentz, Trans. Services Engr., Trans. Services Division State Highway Department State Capitol Building Bismarck 58505

Phillip L. Wilson, State Planning Engineer

Texas State Dept. of Hwys. \& Public Trans.

P. 0. Box 5051

Austin 78703

L. R. Jester, Engineer for Trans. Plan.

Utah Dept. of Trans. 405 S. Main St., Suite 800 Sa1t Lake City 84114

Richard J. Nicholls, Hwy. Plan. Engr., Hwy. Plan. Div.

State of Vermont Dept. of Hwys. State Administration Bldg.

Montpelier 05602

J. Paul Royer, Jr., Dir. of Planning

Dept. of Hwys. \& Trans.

1221 East Broad St.

Richmond 23219

Russell Albert, Planning and Public Trans. Engr.

Department of Trans.

Highway Administration Bldg. Maple Park at Franklin

O1ympia 98501

Fred Vankirk, Chief Engineer - Planning West Virginia Dept. of Hwys. 1900 Washington Street, East Charleston 25305

Thomas J. Hart, Adminis. Division of Planning Department of Transportation 4802 Sheboygan Avenue Madison 53707 
State

Wyoming

\section{Officials}

George H. Bell, Dir. of Plan. and Programming

Plan. and Programming Division

Wyoming Highway Department

Cheyenne 82001 
ORNL/TM-6327

Special

INTERNAL DISTRIBUTION

1. J. T. Arehart

2. S. E. Beall

3. F. D. Boercker

4. D. J. Bjornstad

5. R. S. Carlsmith

6. R. M. Davis

7-9. Energy and Environmental Response Center

10. W. Fulkerson

11-35. D. L. Greene

36. R. F. Hibbs

37. E. A. Hirst

38. D. Jared

39. G. E. Liepins

40-49. A. S. Loeb 1

50-68. T. P. O'Connor

69. M. C. Ogle

70. H. Postma
71. P. L. Rice

72. C. R. Richmond

73. B. R. Rogers

74. A. B. Rose

75. M. W. Rosenthal

76. T. H. Row

77-81. D. B. Shonka

82. M. A. Smith

83. R. L. Spore

84. T. J. Wilbanks

85. D. J. Wilkes

86-87. Central Research Library

88. Document Reference Section

89-91. Laboratory Records

92. Laboratory Records (RC)

93. ORNL Patent Office

\section{EXTERNAL DISTRIBUTION}

94. Assistant Manager, Energy Research and Development, DOE-ORO.

95. Adam Baughcum, Charles River Associates.

96-105. Asil Gezen, TERA, Inc.

106-115. Paul Sverc1, Federal Highway Administration, Washington, D.C.

116-166. Federal Highway Administration, State Divisions.

167-175. Federal Highway Administration, Regional Representatives.

176-226. State Transportation Officia1s.

227-276. Philip D. Patterson, Chief, Data Analysis Branch, Division of Transportation Energy Conservation, United States Department of Energy.

277-414. Regional and Urban Studies Distribution, Energy Division.

415-524. Data Management and Analysis Group, Energy Division, Transportation Energy Conservation Distribution.

524-551. Technical Information Center, Box 62, Oak Ridge, Tenn. 37830. 